\title{
Do compensation consultants enable higher CEO pay? A disclosure rule change as a separating device
}

\author{
Jenny Chu, Jonathan Faasse, and P. Raghavendra Rau*
}

April 2017

\begin{abstract}
We investigate the impact of a firm's compensation consultant choice on executive compensation by examining shifts in consultant choice following a 2009 US Securities Exchange Commission requirement that firms disclose fees paid to compensation consultants for both consulting and other services. We show that the disclosure rule change acted as a separating device distinguishing firms likely to have used compensation consultants to extract rents from shareholders from firms that were likely to have used consultants to optimally set pay. We conclude that not all multiservice consultants are conflicted while not all specialist consultants are guardians of shareholder value. Our study provides a more nuanced view of the association between compensation consultant choices and executive pay.
\end{abstract}

Keywords: Executive compensation, disclosure, governance, regulatory changes

\footnotetext{
${ }^{*}$ Chu and Rau: University of Cambridge, Cambridge Judge Business School, Trumpington Street, Cambridge CB2 1AG, UK; Chu: j.chu@jbs.cam.ac.uk; Rau: +44 1223 761079; r.rau@jbs.cam.ac.uk; Faasse: Independent, jfaasse@gmail.com. We would like to thank Shiva Rajgopal (the editor), two anonymous referees, Lucian Bebchuk, Brian Cadman, Steven Crawford, Patricia Dechow, Aditi Gupta, Alan Jagolinzer, S.P. Kothari, Reuven Lehavy, Gimmy Moore, Richard Sloan, and seminar participants at UC Berkeley, King's College London, the American Accounting Association Conference 2015, the Financial Management Association Conference 2015, and the European Accounting Association Congress 2015 for helpful comments, and the Cambridge Endowment for Research in Finance (CERF) for financial support.
} 
'The upshot is that a mediocre-or-worse CEO - aided by his handpicked VP of human relations and a consultant from the ever-accommodating firm of Ratchet, Ratchet, and Bingo - all too often receives gobs of money from an ill-designed compensation arrangement.'

- Warren E. Buffett, Berkshire Hathaway Inc. 2005 annual report, (2006, p. $\left.16^{1}\right)$

\section{Introduction}

How is Chief Executive Officer (CEO) pay set? Economic theory argues that CEO pay is efficiently set to attract good candidates and provide the optimal level of incentives to motivate the candidates to increase shareholder value (the optimal contracting hypothesis). A large body of literature (see Prendergast, 1999 or Core, Holthausen, and Larcker, 1999) has identified economic determinants of optimal executive compensation. However, an alternative body of literature (see for example, Bebchuk and Fried, 2003, 2004) has argued that CEOs have a great deal of power over the pay-setting decision and use their power to extract rents from the board in the form of excessive pay (the rent extraction hypothesis). As evidence, this literature points to the rapid growth of CEO pay in both absolute and relative terms. The popular press notes for example, that in 2013 CEOs of firms in the Standard and Poor's (S\&P) 500 index were paid, on average, over 200 times the average worker's salary in their firms ${ }^{2}$. Business leaders and politicians, among others, argue that compensation consultants, employed by firms to advise on executive pay, are at least partly to blame for these apparently excessive pay arrangements (see for example, the quote above, Crystal, 1991, or Waxman, 2007).

However, despite extensive research, the extant literature on compensation consultants has found little evidence that hiring consultants leads to higher pay, let alone whether they help set optimal incentives or help managers extract rents. Prior studies have typically classified

\footnotetext{
${ }^{1}$ Retrieved from: http://www.berkshirehathaway.com/2005ar/2005ar.pdf

${ }^{2}$ See for example, Smith, Elliot Blair and Phil Kuntz, 2013, 'CEO pay 1,795-to-1 multiple of wages skirts U.S. law', Bloomberg, April 29, 2013. Retrieved from: https://www.bloomberg.com/news/articles/2013-04-30/ceopay-1-795-to-1-multiple-of-workers-skirts-law-as-sec-delays
} 
consultants on the ex ante likelihood that they will face conflicts of interest in providing advice on executive compensation. For example, consultants who provide multiple services to the firm along with those that are hired by the management are typically hypothesized to be ex ante more conflicted than other consultants. However, whether the consultant is actually conflicted depends on who made the choice to hire the consultant. If the $\mathrm{CEO}$ has relative power over the board, it is plausible that the multiservice consultant could be influenced to favor managers (perhaps by offering them other compensated services). If the board has relative power in the choice, it is plausible that the multiservice consultant provides the best advice at the best price for the additional services rendered, irrespective of the advice provided on executive compensation. Since the underlying decision making process to hire a compensation consultant was unknown, it has been almost impossible for a researcher using standard proxies for corporate governance and CEO power to distinguish the two. Furthermore, even in firms where the consultant is hired by the board consultants may be sensitive to CEO influence. As Bebchuk, Fried, and Walker (2002) note: "even if the CEO is not normally involved in the selection of the compensation consultant, the threat of his involvement the next time-should the consultant suggest a package not to his liking-is likely to keep the consultant in line" (page 790). Hence, ex ante classification schemes have proved unable to separate consultants who have likely been hired to provide optimal compensation schemes from those who have been hired to facilitate rent extraction.

In our paper, we use a comprehensive longitudinal dataset of over 1,000 unique publicly listed firms in the United States (US) that hired compensation consultants over the 2006 to 2012 period. This period is characterized by a change in disclosure rule requirements in 2009 that strikingly increased the turnover of compensation consultants at firms. The disclosure rule change allowed us to separate consultants who were hired for optimal contracting from those who were likely hired to facilitate rent extraction. Specifically, in July 2009, the Securities 
Exchange Commission (SEC) proposed (and subsequently enacted in December 2009) additional disclosure rules requiring firms that purchase other services from their compensation consultants to disclose fees paid for both compensation consulting and other services. If the consultants were retained to solely provide advice on pay, fees did not have to be disclosed. This rule change expanded an existing requirement to disclose use of a compensation consultant, enacted in 2006, and was targeted specifically at clients of multiservice firms, as the significant fees associated with additional services provided by the same firm were suspected of biasing the consultant to favor executives. To illustrate the relative economic significance of these other fees, client firms in our sample reported a median of $\$ 600,435$ of other fees (i.e., 4.4 times the median compensation consulting fee of $\$ 135,380$ ) after the disclosure rule came into effect.

We distinguish between three types of client firms after 2009. Some clients who had previously used multiservice consultants switched to newly spun-off specialist consultants (related switchers), while others switched to unrelated specialists (unrelated switchers). Finally, some stayed with the same multiservice consultants (stayers). Each of these choices had costs and benefits for both the CEO and the board (see Table 1). The relative magnitude of these costs and benefits allow us to distinguish firms where the board is likely to have had power over the choice of consultant from firms where the executive is likely to have had the power. Specifically, we hypothesize that client firms that switched to the newly spun-off related specialist consultants are the ones where the CEO has power over the choice of consultant. In contrast, firms that stayed with their existing multiservice consultants (and explicitly disclosed the amount of consultant compensation) for both executive compensation and other consulting services, or firms that switched to unrelated specialists, are likely to be firms where the board had power over the choice of consultant. 
Consistent with the rent extraction hypothesis, we find that client firms where the board is more likely to be under the influence of the CEO are more likely to switch from a multiservice compensation consultant to a related, spun-off specialist. Comparing CEO pay levels at the stayers against the switchers, client firms that remained with multiservice consultants paid their CEOs $18.32 \%$ (median values) less than a matched sample of firms that switched to the newly spun-off specialist consultants after 2009. In addition, the stayers also paid their CEOs $13.68 \%$ (median values) less in the pre-2009 period. Decomposing total compensation shows that the pay difference is statistically and economically significant for all components of non-incentive and incentive pay in both the pre-2009 and the post-switch periods. This suggests that prior to the rule change, some firms employing multi-service consultants were already paying their executives significantly smaller salaries but these firms could not be distinguished from firms that overpaid their executives. As a robustness check, we also compare CEO pay at stayers against unrelated switchers. Consistent with our expectations, we do not find a significant difference in pay levels in this setting either before or after the 2009 disclosure rule change. We conclude that the behaviour of client firms in response to the 2009 SEC rule change indeed acted as a separating device.

The remainder of this paper is organized as follows. Section 2 reviews the relevant literature. Section 3 examines the compensation consultant industry while Section 4 discusses our data. Our empirical findings are discussed in Section 5, and Section 6 concludes.

\section{Literature review}

A number of business managers, academics, and politicians (including Crystal, 1991; Murphy, 1999; Bebchuk and Fried, 2003, 2004; Buffett, 2006, and Waxman, 2007) contend that powerful CEOs use compensation consultants to justify their high compensation levels to board members, shareholders, and other stakeholders. These critics argue that executives have an incentive to "camouflage" their extraction of rents by the outsider validation of executive 
pay levels. Indeed, this concern contributed to the SEC's initial decision to require publicly traded corporations with fiscal closings on or after December 15, 2006 to identify and describe their use of compensation consultants in their proxy statements.

Subsequent academic studies have examined the effect of consultants on executive compensation levels, using the 2006 ruling to distinguish those firms that use compensation consultants solely for compensation advice and those that use such consultants for other services. They also examine differences between consultants retained by the board and those retained by management, under the premise that the former are more likely to work in the best interests of shareholders. Overall, their results are largely inconsistent with the hypothesis that consultants are used to validate rent extraction.

For example, Cadman, Carter, and Hillegeist (2010) distinguish between consultants that provide compensation services alone and those that provide non-compensation related advice such as advice on pension plans, under the assumption that consultants providing other noncompensation related services will be economically dependent on revenue that is under the control of the CEO. However, they do not find either higher levels of pay or lower payperformance sensitivities for clients of these potentially conflicted consultants. Murphy and Sandino (2010) distinguish between consultants that are hired by management and those that are hired by the board under the presumption that the former are likelier to depend on management favor. Contrary to their hypothesis, they find that pay is lower in US firms when the consultant works for management, rather than for the board.

Studies in other countries, notably the UK, have also yielded mixed results. For example, using a sample of firms from the US and the UK, Conyon, Peck, and Sadler (2009) find that the use of compensation consultants is associated with higher CEO pay after controlling for firm characteristics. However, they do not find any relation between the use of consultants with potential ex ante conflicts of interest and CEO pay levels. In another study, Goh and Gupta 
(2010) find that UK executives receive higher salary increases after their firms switch compensation consultants.

The stability of the firm-consultant relationship has caused researchers to attribute the lack of results to omitted variables. For example, Armstrong, Ittner, and Larcker (2012) (AIL) argue that while CEO pay is indeed higher in clients of consultant firms than in non-consultant firms, this difference is driven by weaker corporate governance at the consultant client firms, not by using consultant firms. AIL find no significant difference in CEO pay levels post-2007 after controlling for corporate governance characteristics. They interpret this finding as consistent with the idea that the costs of high compensation may be offset by the benefits of less intensive monitoring such as greater CEO willingness to share private information with the board (e.g., Adams and Ferreira, 2007 or Laux, 2008). They also find no evidence of higher CEO pay levels at firms that engage multiservice consultants. Murphy and Sandino (2014) document that firms with ex ante higher levels and more complex forms of CEO pay (before hiring consultants) are more likely to use consultants ex post to advise on pay.

With the exceptions of Murphy and Sandino (2014) and Li and Zhang (2014), studies on the role of compensation consultants in the US typically use one or two years of data 20062007 (the period immediately following the SEC's December 2006 rule that required proxy statements to disclose which consultants provided compensation advice to the firm.) $\mathrm{Li}$ and Zhang (2014) find no effect of a post-2009 switch to a specialist on firm CEO compensation levels. However, they expressly exclude firms that switch from multiservice consultants to newly spun-off specialists. Though studies on non-US firms do use longitudinal data, non-US CEOs are also typically paid much smaller amounts than US CEOs, weakening the ability of tests to detect the role played by consultants. 


\section{The compensation consultant industry and regulatory changes}

Compensation consultants can be distinguished according to the types of services they provide. Specifically, compensation-related advice can include an analysis of the compensation of the company's executive officers and board members compared to an appropriate peer group. It can also involve the design of pay programs that are in alignment with the company's business strategy and pay philosophy, industry best practices, compensation trends, and market survey data. Non-compensation advice can include recommendations related to healthcare and pension benefits management, Human Resources (HR) technology/software, or risk management. Typically, the consultant is hired by the compensation committee to provide compensation advice, while the HR department / management hires the consultant to carry out non-compensation consulting services. The HR department /management may also recommend executive compensation consultants to the committee.

Compensation consultants can also be distinguished by whether they have been engaged by the board or the firm's managers. However, this is a noisy measure of the potential for conflicts of interests. Bebchuk, Fried and Walker (2002) note that "compensation consultants are hired through a company's human resources department, and anecdotal evidence suggests that some CEOs are heavily involved in the process" (page 790). "Even if the CEO is not normally involved in the selection of the compensation consultant", they argue, "the threat of his involvement the next time - should the consultant suggest a package not to his liking - is likely to keep the consultant in line". Hence, it is not clear that consultants hired by the board are relatively unconflicted relative to consultants hired by management. Even if a consultant is retained by the board for compensation consulting, management can subsequently influence the consultant by paying for other services. Likewise, a multiservice consultant engaged to provide only compensation consulting has an incentive to sell additional non-executive 
compensation services to the firm (potentially through the CEO), even though the firm may not be currently paying for any other services.

Due to the potential conflict of interest in the engagement of multiservice consultants, in 2009 the SEC proposed additional disclosure rules for firms that hired compensation consultants. The SEC received 130 comment letters in response to its proposed amendments, with most investors in favor of the amendments and most multiservice consultants against them. ${ }^{3,4}$ Specifically, the multiservice firms argued that the amendments would have a negative economic impact on their future business prospects as firms would be discouraged from using multiservice compensation consulting firms in more than one capacity.

After receiving the comment letters, the SEC adopted a modified version of the proposed amendments in December 2009 to take effect for all proxy filings after February 2010. The modified ruling indicates that if a board's consultant or its affiliates provide other nonexecutive compensation consulting services, the client firm is required to disclose the fees paid when the non-executive compensation consulting service fees exceed $\$ 120,000$ during the fiscal year. If the board does not engage the consultant, then the same disclosure is also required of consultants that work directly for the company or for management.

The disclosure change was intended to ensure the independence of compensation consultants hired directly by a firm's compensation committee. The consultant industry, especially those multiservice providers most affected by the new disclosure rules, reacted quickly to this mandate. In February 2010, a select number of principals and consultants left Hewitt Associates, one of the four largest multiservice consultants by market share, to form Meridian Compensation Partners LLC, an entity which would operate as an independent executive compensation consulting firm. According to the related press release:

\footnotetext{
${ }^{3}$ See for example, letters from AFL-CIO, Frank Inman, Hermes Equity Ownership Services Ltd., TIAA-CREF, and Trillium Asset Management. Retrieved from: https://www.sec.gov/rules/final/2009/33-9089.pdf

${ }^{4}$ See for example, letters from ABA, Hewitt, Mercer, Pfizer, Protective Life Corporation, Radford, Towers Perrin, Value Alliance, and Watson Wyatt. Retrieved from: https://www.sec.gov/rules/final/2009/33-9089.pdf
} 
'This spin-off keeps those clients' best interests in mind-they can continue to work with their current executive compensation advisor and team, without compromising the appearance of independence...At the same time, it creates opportunities for us to expand our relationships with those clients that may have felt restricted from engaging Hewitt for broader consulting and outsourcing work because we were the executive compensation consultant to their board. ${ }^{5}$

Other compensation consultants acted similarly. In 2009, a group of former Mercer partners launched Compensation Advisory Partners, their own new executive compensation consulting firm while in 2010, Towers Watson announced that it would partner with a newly created spinoff, Pay Governance LLC.

Given the resulting structural changes in the compensation consulting industry, the 2009 SEC ruling presents an opportunity for us to study the relation between a firm's incentives in engaging a compensation consultant and that firm's CEO pay level. The choice of a compensation consultant can either be made by the CEO or the board. Since this choice is invisible to the econometrician, prior papers were not able to distinguish firms where the board is likely to have made the choice of consultant from firms where the CEO is likely to have made the choice.

We hypothesize that the 2009 rule change acts as a natural separating device that separates firms where the CEO made the choice from firms where the board made the choice. Table 1 sets out our hypotheses for the costs and benefits of each choice and for who is likely to have made the choice of consultant. Following the rule change, the firm makes one of three decisions: Switch to a related spin-off consultant, switch to an unrelated specialist, or remain with a multiservice consultant. Regardless of the actual magnitudes of benefits and costs, only

\footnotetext{
5 'Hewitt Associates announces partial spin-off of its executive compensation consulting business in North America,' February 1, 2010, Business Wire. Retrieved from: http://www.businesswire.com/news/home/20100201005487/en/Hewitt-Associates-Announces-Partial-Spin-OffExecutive-Compensation
} 
the first decision - to shift to a related spin-off consultant - has no costs for the CEO and potentially some large benefits. We therefore classify this type of switch as likely to have been decided by the CEO. Firms characterized by this decision are likely to have weaker corporate governance and be prone to agency problems. In contrast, firms that stayed with their existing multiservice consultants (and explicitly disclosed the amount of consultant compensation) for both executive compensation and other consulting services, seem to offer no incremental benefit for the CEO and potentially offer incremental costs. We therefore classify firms that remained with multiservice consultants as firms where the board had power over the choice of consultant. Finally, firms that switched to unrelated specialists offer some benefits but also significantly larger incremental costs. We also classify this switch as likelier to have been made by the board than the CEO.

\section{Sample and variables}

\subsection{Sample construction}

To examine this relation, we use a sample of 1,051 unique publicly listed firms and 6,241 firm-years from 2006 to 2012. As in AIL, we exclude firms with fiscal years ending before December 2006 to ensure that all firms in our sample are subject to the compensation disclosure requirements that took effect on December 15, 2006.

Our data on compensation consultant usage come from Incentive Lab's executive compensation database. This is a proprietary dataset that provides information from firm proxy statement disclosures regarding their compensation consultant usage, including details on consultants retained in each fiscal year. From this dataset, we obtain our initial sample of 7,580 firm-years, of which 6,765 disclose the hiring of a compensation consultant. We then eliminate any firm-years that do not have corresponding data in the ExecuComp database (which details executive compensation for S\&P 1000 firms) to ensure compensation data and CEO 
characteristics are consistent with the samples in previous studies. The restriction reduces our final sample to 1,051 unique firms and 6,241 firm-year observations.

Table 2 Panel A shows the distribution of consultant and non-consultant firms across the sample period. Over our sample period, we find that approximately $90 \%$ of ExecuComp firmyears disclose the use of compensation consultants. This proportion is consistent with that found in previous studies on compensation consultants. Furthermore, each year, approximately $28 \%$ of those firms not using compensation consultants in the previous year choose to do so for the first time. Around the time of the disclosure rule change, Table 2 Panel A also shows, a large proportion of firms switch consultants. Specifically, 33.2\% of our firms switch consultants in 2009 and $39.6 \%$ switch in 2010 , in contrast to an average of $29.5 \%$ over the entire period. Table 2 Panel B shows that no industry dominates the distribution of firms using a consultant versus non-consultant firms.

Table 3 presents our summary statistics for the compensation consultant industry. Averaging across yearly averages in Panel A reveals that specialist consultants represented $38.8 \%$ and $60.8 \%$ of our sample from $2006-2008$ and $2009-2012$, respectively. The market share of specialist consultants increased every year from $35.4 \%$ in 2006 to $70.4 \%$ in 2012 . Of particular note, there appears to be a sharp structural break in the composition of the industry in 2010 when the market share of specialist consultants jumped from $44.3 \%$ to $59.3 \%$. There are several reasons for this break. First, following the 2009 SEC ruling, new specialist firms (Pay Governance, Meridian, and Compensation Advisory Partners) were spun-off from multiservice providers, accounting for $14.9 \%$ of the market in fiscal 2010 and $20.3 \%$ by fiscal 2012. Second, Panel B of Table 3 indicates that existing specialist consultants (Frederic W. Cook, Pearl Meyer, Compensia, and Semler Brossy) also enjoyed an increase in market share during this time, from $29.1 \%$ in fiscal 2008 to $35.6 \%$ in fiscal 2012. During this same period, 
the large multiservice compensation consultants, Towers Watson, Aon Hewitt and Mercer dropped from a collective market share of $53.1 \%$ in fiscal 2008 to $24.9 \%$ in fiscal 2012.

Table 3 Panel B illustrates this market share evolution at the individual compensation consultant level. Before the 2009 SEC disclosure rule change, Towers Watson's predecessor (Towers Perrin), Aon Hewitt's predecessor (Hewitt \& Associates), Frederick W. Cook and Mercer each accounted for over $10 \%$ of the market, while Pearl Meyer accounted for another 4.8\%. The rest of the market was fragmented. After the 2009 rule change was announced, the top three multiservice providers, Towers Watson, Hewitt, and Mercer spun off the compensation specialist consultants Pay Governance, Meridian, and Compensation Advisory Partners, respectively. Existing large specialist firms Frederic Cook and Pearl Meyer gained market share between 2009 and 2012, with Frederic W. Cook becoming the market leader at $19.7 \%$ market share in 2012.

Finally, the statistics in Table 4 Panel A1 show that, by 2012, 26.8\% of those client firms affected by the rule change switched to a related spun-off specialist, while Panel A2 shows that only $2.6 \%$ of unaffected client firms did so. Additionally, we find that client firms that engaged multiservice consultants and were required to disclose fees from 2009 onwards reported median fees for other services of a magnitude 4.4 times larger than their executive compensation consulting fees $(\$ 600,435$ and $\$ 135,380$, respectively, reported in Table 4 Panel B).

Taken together, the statistics in Tables 2 and 3 provide preliminary evidence that the compensation consultant industry experienced significant structural changes in response to the 2009 SEC disclosure requirement. 


\subsection{Variables and descriptive statistics}

As in previous studies, our main variable of interest is the total amount of CEO compensation at the firm level. To measure CEO compensation, we use the TDC1 variable from ExecuComp, which includes salary, bonus, non-equity incentive plan compensation, grant-date fair value of stock awards, grant-date fair value of option awards, deferred compensation, and other compensation. Note that this definition applies to ExecuComp data from 2006 onward.

In our study, we control for firm, CEO, ownership, and board characteristics that may influence both compensation levels and the likelihood of retaining a compensation consultant. For firm characteristics, we follow AIL and control for firm size using the natural logarithm of market capitalization, $\log$ (market capitalization), at the beginning of the fiscal year; the bookto-market ratio at the beginning of the fiscal year; return on assets for the prior fiscal year $(R O A)$, calculated as operating income after depreciation (Compustat OIADP, following the convention in the accounting literature) for the prior fiscal year scaled by total assets at the end of the prior fiscal year; the change in return on assets $(\triangle R O A)$ between the current fiscal year and the prior fiscal year; and the raw stock return of the prior two fiscal years. Furthermore, we control for firm complexity using the natural logarithm of the number of business segments, $\log$ (\# business segments). We also control for firm growth using asset growth and employee growth over the prior year. We calculate our accounting variables using data from Compustat and our market variables using data from the Center for Research in Security Prices (CRSP).

In addition to firm characteristics, we control for several CEO characteristics: the CEO's proportion incentive pay, computed as the proportion of long-term incentive compensation (TDC1 - Salary - Bonus) to total compensation; $C E O$ age; $C E O$ tenure; and whether the CEO is a new $C E O$ in the current fiscal year. As a measure of the CEO's equity incentives, we calculate the CEO's firm-related wealth, using the methodology outlined in Daniel, Li, and 
Naveen (2013) (see also Coles, Daniel, and Naveen, 2013). In addition, we define Founder CEO following the approach of Bebchuk, Cremers, and Peyer (2011).

We also control for the ownership structure of the firm, specifically the degree of institutional ownership of a firm as well as the number of block holders (defined as the number of institutions with $5 \%$ or more ownership of outstanding shares), using data obtained from Thomson Reuters 13F holdings data.

Finally, we control for several board characteristics that have typically been used in the prior literature as proxies for the strength of corporate governance at the firm. These include the size of the board of directors, board size; the proportion of board members who are independent directors, \% independent board; the proportion of board members who also serve on another board, \% board busy; the proportion of board members who are at least 69 years of age, \% board old; whether the CEO is also the chairman of the board, CEO is Chairman; whether board members have staggered election terms, staggered board; and finally whether there is more than one class of shares, dual class shares. We also control for the proportion of board members who have joined since the CEO's tenure began at the firm (\% board appointed by $C E O$ ), since these are likely to be board members over which the CEO had influence (Bebchuk, Fried, and Walker, 2002; Armstrong, Jagolinzer and Larcker, 2010).

Since the consultant's advice to the board is typically delivered to the compensation committee, we further control for the following characteristics of the compensation committee: the proportion of committee members who serve on another committee or board, Comp. committee \% busy; the proportion of committee members who are at least 69 years of age, $\%$ old; and the number of members on the compensation committee, size. With the exception of our $C E O$ is Chairman variable, which is collected from ExecuComp, all other governance variables are calculated using data collected from the RiskMetrics Directors and Governance datasets. (See Appendix II for data definitions.) 
As mentioned, we classify the compensation consultants in our study by whether they provide other consulting services in addition to compensation consulting. Specialist consultants provide only a narrow range of compensation-related services and include the following firms: Pay Governance, Meridian, Frederic W. Cook, Compensation Advisory Partners, Pearl Meyer, Compensia, Semler Brossy, and Exequity ${ }^{6}$. In contrast, multiservice consultants provide a range of human resource (HR) and other services in addition to compensation consulting and include the following firms: Towers Watson (and predecessors Towers Perrin, and Watson Wyatt), Aon Hewitt (and predecessors), Mercer and Radford, McLagan and Hay ${ }^{7}$. Appendix I details how we classify a firm's switch to a related specialist consultant.

Table 5 reports the descriptive statistics for our sample. From Panel A, we see that firms that use compensation consultants are, on average, larger, more complex (as measured by the number of business segments), and have lower asset and employee growth than those that do not hire compensation consultants, but are otherwise similar in terms of most other firm characteristics. We find no statistically significant differences in the level of institutional ownership between consultant client-firms and those that do not engage such consultants. However, the statistics in Panel A show that the two sets of firms differ substantially on CEO and corporate governance characteristics. Specifically, CEOs of firms employing consultants earn higher pay, of which there is a higher proportion of incentive pay, and that they have lower firm-related wealth. In terms of board characteristics, while these firms are less likely to have dual class shares, they are more likely to have a staggered board. Firms that retain consultants have larger boards, a higher proportion of independent directors, and a higher proportion of busy directors. Turning to the compensation committee more specifically, firms with consultants have significantly younger, busier, and larger compensation committees.

\footnotetext{
${ }^{6}$ Exequity is not tabulated in Table 3 as it is not one of the top 15 firms by market share.

${ }^{7}$ Radford, McLagan, and Hay is not tabulated in Table 3 as it is not one of the top 15 firms by market share.
} 
Panel B of Table 5 presents the summary statistics for our subsample of firms that change compensation consultants on or after 2009. Overall, firms that switch to related specialist consultants (column 2) are, on average, larger but less complex. They have higher stock performance the year prior to the switch and lower operating performance than firms that stay with multiservice consultants (column 1). Firms that switch to related specialists appear to have lower institutional ownership and fewer block holders than those who do not change consultants. Regarding CEO characteristics, firms that switch to related specialists have CEOs who are older, have been with the firm for a shorter period, and have a higher proportion of their compensation tied to incentives and firm-related wealth. Regarding board structure, these firms have boards that are larger, older, busier, and more independent. Overall, our summary statistics appear to show a similar pattern for consultant-client and non-consultant-client firms as that found in previous literature, and offer preliminary evidence that weaker governance does appear to affect the switch to consultant-spinoff matches that might help increase compensation ex post.

Finally, in untabulated correlation results, we find that compensation is strongly correlated with consultant use, firm size, firm profitability, the CEO pay mix, and firm-related wealth. However, it is inversely correlated with a firm's book-to-market ratio. We also find that total compensation is positively and significantly correlated with board size, the proportion of independent directors on the board, the proportion of board members who are busy, and whether the CEO is also the chairman of the board.

\section{Empirical results}

\subsection{Compensation consultant use and CEO pay}

We first examine why firms choose to engage compensation consultants. In previous research, AIL find that controlling for economic and corporate governance characteristics mitigates any difference in the level of CEO pay at firms that use compensation consultants. In 
other words, the hiring of compensation consultants can be seen as a manifestation of weaker corporate governance at the firms that hire them. Since the CEOs at these firms would receive a higher level of pay regardless of whether they engage compensation consultants, the hiring of such consultants prior to the rule change was likely used to provide external validation of a CEO's compensation level to the firm's board. This argument is consistent with our finding that firms with consultants also tend to have larger boards, a higher proportion of independent directors, and a higher proportion of busy directors.

To examine the incentives in choosing to engage a compensation consultant, we follow AIL's methodology in matching treatment samples of those firms that hire compensation consultants with samples of those that do not, using propensity scores of the likelihood of having a compensation consultant calculated from a combination of economic and corporate governance factors. Specifically, we pair each treatment firm-year with one control firm-year (in the same year), using caliper matching (with a caliper of 0.05 , without replacement). After matching, we then compare the covariates between the treatment and control groups with a two-sample t-test and a two-sample Kolmogorov-Smirnov test. In those cases where the propensity-based matching yields unbalanced covariates, we calibrate by requiring the covariates to be within a similar neighborhood. This process slightly reduces our overall sample size. The number $(\mathrm{N})$ of matched-pairs is reported in tables 6 and 7.

Table 6 presents the results from our logistic regression on the determinants of consultant use. Following AIL, we present the results on the determinants of whether a firm uses a compensation consultant in column 1. Consistent with prior research, we find that firms that hire compensation consultants tend to be those with lower operating performance and greater reliance on long-term incentive pay. Firms that use compensation consultants also tend to have CEOs who have a shorter tenure, and lower existing firm-related wealth. We also find that at 
compensation consultant client firms, boards tend to be larger and more independent while members of the compensation committee are younger and busier.

We investigate the determinants of firms switching to a related spun-off consultant rather than staying with the existing multiservice consultant in column (2). We find that larger, slower growth, and less profitable firms that pay a bigger proportion of incentive compensation tend to switch from their multiservice consultants to related, spun-off specialists. These switching firms also have busier compensation committees and lower institutional ownership. These results are consistent with the idea that firms where CEO's influence on boards is higher tend to switch to the related, spun-off specialists.

We further examine the firms' choice set in a multinomial ordered logistic regression. We use an ordered logit in preference to a standard multinomial logit because Table 1 suggests the likelihood that the CEO chooses the consultant (rather than the board) decreases monotonically from the decision to switch to a related spun-off consultant to switching to an unrelated consultant to staying with the multiservice consultant. In the ordered logistic regression, the baseline is therefore whether the firm switches to a related spinoff specialist. For ease of interpretation, we code the dependent variable as zero if the firm switches to a related specialist, 1 if it switches to an unrelated specialist, and 2 if it stays with the multiservice consultant. The results presented in column (3) of Table 6 indicate that firms that are smaller, and higher growth firms with fewer segments are more likely to stay with multiservice consultants. These firms also have older CEOs and a lower proportion of incentive pay. In terms of governance characteristics, and consistent with the idea that firms that choose to stay with multiservice consultants (and disclose both executive compensation and other consulting fees) have better governance, these firms have higher institutional ownership and their compensation committee members are less busy. 
We next evaluate the efficacy of our matching algorithm by examining the covariate balance between the matched pairs within each consultant category. The results in Table 7 Panel A show that our two matched groups (after matching using model (1) in Table 6) appear similar with respect to their observable contracting environments. The results in Table 7 Panel B show that CEO pay is significantly higher at firms with consultants even after controlling for firm, CEO, and governance characteristics (mean and median differences of $22.29 \%$ and $21.40 \%$, respectively, significant at $1 \%$ confidence levels). ${ }^{8}$

We then decompose total compensation into salary and benefits (total compensation minus cash-incentive, and equity based pay), cash-incentive (non-equity incentives and bonus), and equity (option and stock awards) categories. To mitigate potential outlier effects, we discuss median differences in the text. Panel B shows that the salary and benefits earned by CEOs at firms that use compensation consultants is higher by a median $3.55 \%$ while equity pay is higher by a median $15.49 \%$, statistically significant at the $1 \%$ level. Furthermore, we find that firms that use compensation consultants provide greater proportions of incentive and equity incentive pay but are similar to non-consultant firms in stock returns, ROA, employees, and asset growth. We also test whether firms with compensation consultants are likely to have more complex compensation contracts for lower-ranking employees by comparing the percentage of CEO and top 5 executive option pay as a percentage of the firms' total stock option expense. If a firm has more widespread stock-based incentive compensation for employees, the share of CEO and top 5 executive option pay should be smaller. We do not find a statistically significant difference in the share of CEO and top 5 executive option pay between the consultant client firms and matched firms. ${ }^{9}$

\footnotetext{
${ }^{8}$ In contrast, AIL find that for a sample of S\&P1500 firms in 2006, the difference in total compensation between consultant client firms and matched firms is not statistically significant after controlling for governance characteristics in the propensity-score matching procedure.

${ }^{9}$ An additional possibility is that consultants are specifically hired by firms with hard-to-value tasks such as repricing underwater options (perhaps because restructuring these options are complex). If this were true, we should find that there should be significant differences between firms that hire consultants and those that do not
} 
Based on our results, and contrary to previous studies, we conclude that CEO pay levels at firms that use compensation consultants are economically and statistically significantly higher than those at firms that do not use consultants. ${ }^{10}$ However, given the nuanced pay proportion differences described above, our results can be interpreted as evidence of the existence of either rent extraction or optimal compensation incentives.

\subsection{Multiservice versus specialist consultants}

We next turn our attention to the relation between executive compensation and the type of consultant used by a firm. Previous research (e.g., Crystal, 1991; Bebchuk and Fried, 2004) posits that multiservice compensation consultants may be influenced by managers who have the opportunity to engage these consultants for other services. Indeed, this possibility influenced the 2009 SEC ruling requiring disclosure when the non-compensation consulting fees paid to a multiservice consultant exceed $\$ 120,000$ for the year.

To avoid disclosing these fees after the ruling, clients of multiservice firms had the choice of using a specialist consultant for executive compensation advice while using a multiservice consultant for other services. In other words, client firms that engaged multiservice consultants for both executive compensation services and other services before 2009 could choose to switch to either a related, newly spun-off specialist consultant or an unrelated specialist for executive compensation advice while using the same or another multiservice consultant. Alternatively, the client firm could remain with the existing multiservice firm for both

\footnotetext{
in the level of underwater options in the firm. Since we do not know when the options were granted (and hence do not know when the options are underwater), we assume a three-year vesting period and compare the stock price decline for the firm in 2008 relative to its 2005-2007 average (Price in 2008 Relative to 2005-2007 Average). Consistent with this hypothesis, firms that employee compensation consultants do appear to have significantly greater price declines than firms who do not hire consultants.

${ }^{10}$ Since our matched-pairs methodology reduces our sample size, we also regress total CEO compensation on firm, CEO, and governance characteristics plus an indicator variable that equals 1 for consultant client firms on our full sample. In this analysis, we include industry and year fixed effects, and cluster standard errors at the firm level. The untabulated results, using the full sample of 6,056 firm years, indicate that the coefficient of consultant usage in the regression using the natural logarithm of total compensation as the dependent variable is 0.30 (pvalue $<0.01)$.
} 
compensation consulting and other services and, as noted above, disclose consultant compensation if fees for other services exceeded \$120,000. (See Appendix I for switching definitions.)

We hypothesize that firms that originally used multiservice consultants to influence executive compensation advice upwards should react to the 2009 ruling by switching to spunoff specialists. In contrast, firms that did not use multiservice consultants to influence executive compensation should react to the 2009 ruling by either switching to unrelated specialists or remaining with their multiservice consultants.

The results in Table 8 Panels A1 and A2 show that the difference in total pay between the treatment group of those who stay with their consultants and the control group of propensityscore matched switchers is significant both before and after $2009 .{ }^{11}$ Specifically, we find that CEOs at firms that remain with multiservice consultants earn a $13.68 \%$ lower median pay before 2009 and a $18.32 \%$ lower median pay after 2009 than their peers that switch to related specialist consultants after 2009. When total pay is further decomposed into salary and benefits, cash-incentive compensation, and equity pay, firms that switch to related specialists award higher CEO pay in all three categories, even though firm performance does not consistently differ across the treatment and matched samples. Importantly, while the dollar amount of incentive pay was higher for CEOs at these firms, the proportion of incentive pay is not significantly different. Specifically, while the proportion of incentive pay for firms that switched to related spun-off consultants was 1.3 percentage points higher prior to 2009 , the difference is no longer statistically significant after 2009. Table 8 Panels A1 and A2 also shows that other compensation practices such as CEO deferred compensation and options, as well as

\footnotetext{
${ }^{11}$ Untabulated results indicate that our two matched groups have similar covariates for the propensity-score matching variables that describe firm, $\mathrm{CEO}$, and governance characteristics. We obtain similar results if we exclude firms with founder CEOs from the sample.
} 
firms' option pay to the top 5 executives and employees do not seem to differ across the treatment and control groups.

These results support the hypothesis that at least some firms use compensation consultants to justify executive pay, even when such pay packages are less closely aligned with shareholder interests. Anecdotal evidence supports this hypothesis. In a number of instances after the 2009 ruling, compensation consultants who enjoyed an especially close relationship with a firm's management chose to join specialist firms. ${ }^{12}$

As a robustness check, we also compare CEO pay at stayers against unrelated switchers. Consistent with our expectations, the results in Table 8 Panels B1 and B2 show that there are no significant differences in total and non-incentive compensation levels in this setting either before or after the 2009 disclosure rule change. Firms that retain their multiservice compensation consultants after the 2009 ruling, compared to those that switch to unrelated specialists, have lower cash incentive pay levels and higher equity incentive pay proportions prior to 2009, and lower equity pay levels after 2009. These results are consistent with the hypothesis that the switchers to unrelated specialists potentially did so to re-align compensation component choices between cash incentive pay and equity based incentive compensation, and that these switchers are unlikely to have switched to enable CEO rent extraction ${ }^{13}$. Note that

\footnotetext{
${ }^{12}$ For example, the following explanation on consultant turnover is extracted from the fiscal 2009 proxy statement for Scientific Games Corporation:

'The Committee has in the past retained Mercer LLC ('Mercer') as its outside compensation consultant. In October 2009, the Committee determined to instead engage Compensation Advisory Partners LLC, as the consultant from Mercer that had traditionally worked with the Committee moved to Compensation Advisory Partners LLC. In addition, the Committee believed this change would eliminate any appearance that the advice received from its outside compensation consultant is not independent, since Compensation Advisory Partners LLC provides no services to the Company other than those provided to the Committee, whereas Mercer has been engaged by management to provide health and welfare, pension and general compensation consulting services ("Other Services").'

Hence Scientific Games Corporation chose to continue working with the lead consultant from Mercer on executive compensation consulting after the individual moved to a specialist firm but chose to retain Mercer for other services.

${ }^{13}$ In addition, the proportion of CEO deferred compensation at firms that remain with multiservice compensation consultants after 2009 is higher than those that switch to unrelated specialists. The median differences in the proportion of CEO deferred compensation is statistically significant (10\% confidence levels prior to 2009 and 5\% confidence levels post 2009), but are not economically significant (less than 0.1 percentage points).
} 
we use the stayers as the treatment group in both Panels A and B to ensure that the same group of firms is compared to the related and unrelated switchers, respectively.

The difference in differences for median values of total and component compensation levels between the matched groups in Table 8 are not statistically significant between the pre and post 2009 periods. This suggests that prior to the rule change, some firms employing multiservice consultants were already paying their executives significantly smaller salaries but these firms could not be distinguished from firms that overpaid their executives without a way to separate the two types. Taken together, these results from Table 8 support our conjecture that the differences in pay before the rule change could have been driven either by the optimal contracting hypothesis or the rent extraction hypothesis. The rule change acted as a separating device distinguishing firms that switch to related spun-off specialists to obtain favourable pay advice from those that stayed with existing multi-service consultants or switched to unrelated specialists.

\subsection{CEO pay effects from the initial use of consultants}

In addition to allowing us to better understand the effect of the 2009 ruling on executive compensation levels, our panel data from 2006-2012 also enables us to relate changes in pay to the initial adoption of consultants. This in turn helps alleviate concerns over correlated omitted variables. In one previous study examining the adoption of compensation consultants, Goh and Gupta (2010) find no significant relationship between first-time compensation consultant hiring and executive director pay changes for a sample of UK firms. In a study of US firms, Cadman, Carter, and Hillegeist (2010) find preliminary evidence that adding compensation consultants is not associated with pay increases for CEOs. However, it should be noted that there are only 24 firms that started hiring consultants in 2007 in their sample. In contrast, in our expanded sample, we have 106 firms that started hiring consultants during our sample period. Thus, we are able to obtain matched control firms based on firm, CEO, and 
governance characteristics. We exclude firm-years when a new CEO is hired, as this event may introduce an endogenous bias regarding CEO pay. ${ }^{14}$ Finally, to explore whether the initial hiring of a compensation consultant is associated with a higher increase in total pay, we compare the total pay of our treatment and propensity-score matched samples.

Table 9 presents the results from our matched-pairs analysis of compensation changes and initial adoption of consultants for the full 2006-2012 longitudinal dataset. ${ }^{15}$ The results indicate that the mean difference in total compensation change upon compensation consultant adoption is $15.98 \%$, and the difference is statistically significant at the $5 \%$ confidence level (the median difference is not statistically significant at the $10 \%$ confidence level $)^{16}$. In particular, mean (median) change in equity pay is $19.93 \%(2.14 \%)$ and the change is statistically significant at $5 \%(10 \%)$ confidence levels and the mean (median) change in equity pay as a proportion of total pay is 6.9 percentage points ( 0.3 percentage points). There are no significant differences in total and sub-category compensation levels and proportions before the adoption of compensation consultants and that firm performance measures are largely not statistically significantly different across the matched samples. Firms may also hire compensation consultants due to a need for overall employee compensation advice. Consistent with this hypothesis, employee growth at firms that adopt compensation consultants is on average 4.1 percentage points higher than the control group, and the difference is statistically significant at the $5 \%$ confidence level (though the median difference is insignificant). When we decompose total compensation into its non-incentive, cash-incentive, and equity components, we find that the median difference in compensation changes after the adoption of a compensation consultant

\footnotetext{
${ }^{14}$ Including these firm-years does not change our results.

${ }^{15}$ Untabulated analysis shows that the mean and median covariates in terms of firm, CEO, and governance characteristics between the treatment and control groups are not significantly different.

${ }^{16} \mathrm{We}$ also rerun our analyses using the regression approach employed by Cadman, Carter, and Hillegeist (2010) and Goh and Gupta (2010). This approach yields a coefficient of 0.15 for our indicator variable (initial adoption of a compensation consultant) from an untabulated regression where the dependent variable is the change in logged total compensation.
} 
appears to be largely driven by an increase in the proportion of the equity component of pay (6.9 percentage mean and $0.3 \%$ median), a result that is consistent with pay being more closely tied to shareholder value. While there is no difference in CEO's deferred compensation as a proportion of total compensation pre-adoption, the deferred compensation proportion decreased by a mean of 0.7 percentage points which is significant at the $5 \%$ confidence level (median change is statistically insignificant) upon the hiring of compensation consultants. As discussed previously, the 2009 rule change acts as a natural separating device to separate firms that are likely to be driven by rent extraction from those who contract optimally with their CEOs. Firms that initially hire compensation consultants do not necessarily fall into either bucket and hence it is not surprising that we find evidence of optimal contracting in this setting. Since firms have different reasons to start hiring compensation consultants, the initial adoption of compensation consultants appears to provide evidence for both rent extraction and optimal contracting. Our evidence shows the difficulty prior research has had in distinguishing client firms that use compensation consultants to justify higher pay from those that use consultants to structure optimal contracts.

\section{Conclusions}

While a number of studies have examined the effect of compensation consultants on overall executive pay levels, this research has largely focused on the one- or two-year period surrounding the 2006 SEC ruling that firms identify their compensation consultants in their proxy statements. This limited sample timeframe may explain why previous research has found little evidence that using compensation consultants leads to higher CEO pay at firms.

In our paper, we expand our timeframe to the period between 2006 and 2012. Using a dataset of over 1,000 firms, we analyze the relation between consultant use and CEO pay. In addition, we use the 2009 SEC ruling on the disclosure of non-compensation consulting fees 
as a natural device to separate the firms in our study based on their incentives in the choice of a compensation consultant.

We show that firms that switch to a spun-off specialist after the 2009 ruling pay their CEOs significantly more than do a matched sample of firms that remain with their multiservice consultants. We interpret this finding as evidence that firms that switch to spun-off specialists are motivated by a desire to obtain favorable compensation advice. Over our entire sample period, we find that firms experience a significant increase in CEO pay when they initially hire a compensation consultant relative to a propensity-score matched sample, but the increase in total pay is largely due to higher equity based incentive pay. Overall, our study provides new and more nuanced empirical evidence that some firms adopt compensation consultants to design optimal pay packages whereas other firms use compensation consultants as a justification for higher executive pay levels. On a broader level, our findings suggest that not all multiservice consultants are conflicted and not all specialist consultants are guardians of shareholder value. 


\section{REFERENCES}

Adams, R. B., D. Ferreira. 2007. A theory of friendly boards. Journal of Finance. 62 217-250.

Armstrong, C S., C. D. Ittner, D. F. Larcker. 2012. Corporate governance, compensation consultants, and CEO pay levels. Review of Accounting Studies. 17 322-351.

Armstrong, C S., A. D. Jagolinzer, D. F. Larcker. 2010. Chief executive officer equity incentives and accounting irregularities. Journal of Accounting Research. 48 (2) 225-271.

Bebchuk, L. A., K. J. M. Cremers, U. C. Peyer. 2011.The CEO pay slice. Journal of Financial Economics. 102 199-221.

Bebchuk, L. A., J. Fried. 2003. Executive compensation as an agency problem. Journal of Economic Perspectives. 17 71-92.

Bebchuk, L. A., J. Fried. 2004. Pay without performance: The unfulfilled promise of executive compensation. Cambridge: Harvard University Press.

Bebchuk, L. A., J. Fried, D.I. Walker. 2002. Managerial power and rent extraction in the design of executive compensation. The University of Chicago Law Review. 69 751-846.

Buffett, W. 2006. Berkshire Hathaway Inc 2005 annual report. Available at: http://www.berkshirehathaway.com/2005ar/2005ar.pdf

Cadman, B., M. E. Carter, S. Hillegeist. 2010. The incentives of compensation consultants and CEO pay. Journal of Accounting and Economics. 49 263-280.

Coles, J. L., N. D. Daniel, L. Naveen. 2008. Boards: Does one size fit all? Journal of Financial Economics. 87 329-356.

Coles, J. L., N. Daniel, L. Naveen. 2013. Calculation of compensation incentives and firmrelated wealth using ExecuComp: Data, program, and explanation. Working Paper, available at http://papers.ssrn.com/sol3/papers.cfm?abstract_id=2296381

Conyon, M., S. Peck, G. Sadler. 2009. Compensation consultants and executive pay: Evidence from the United States and United Kingdom. Academy of Management Perspectives. 23 4355.

Core, J. E., R. W. Holthausen, D. F. Larcker. 1999. Corporate governance, chief executive officer compensation, and firm performance. Journal of Financial Economics. 51 371-406.

Crystal, G. S. 1991. In search of excess: The overcompensation of American executives. New York: W.W. Norton.

Daniel, N., Y. Li, L. Naveen. 2016. Asymmetry in pay for luck: A size effect? Working paper, available at http://papers.ssrn.com/sol3/papers.cfm?abstract_id=2160015

Goh, L., A. Gupta. 2010. Executive compensation, compensation consultants, and shopping for opinion: Evidence from the UK. Journal of Accounting, Auditing and Finance. 25 607-643.

Laux, V. 2008. Board independence and CEO turnover. Journal of Accounting Research. 46 137-171. 
Li, W., H. Zhang. 2014. Does the mandatory conflict-of-interest disclosure affect firms' choice of compensation consultants? Working paper, available upon request from huaizhang@ntu.edu.sg

Murphy, K. J. 1999. Executive compensation. Chapter in Ashenfelter, O. and D. Card, Handbook of Labor Economics 4A. Amsterdam: Elsevier.

Murphy, K. J., T. Sandino. 2010. Executive pay and 'independent' compensation consultants. Journal of Accounting and Economics. 49 247-262.

Murphy, K. J., T. Sandino. 2014. Are consultants to blame for high CEO pay? Working paper, available at

https://accounting.wharton.upenn.edu/acct/assets/File/Consultants\%20Turnover-3-20-2014Wharton.pdf

Prendergast, C. 1999. The provision of incentives in firms. Journal of Economic Literature. 37 7-63.

Waxman, H. 2007. Executive pay: Conflicts of interest among compensation consultants. Committee on Oversight and Government Reform, U.S. House of Representatives. 


\section{Appendix I. Switching Definitions.}

\section{$\underline{\text { Switch to a Related Specialist Consultant }}$}

For the matched pairs analysis in Table 8A, a firm is defined as switching to a related specialist consultant in 2009 or after if:

a) the firm retains Towers Watson (or one of its predecessors) and no other specialist consultant, and in the following period retains Pay Governance as a compensation consultant; or

b) the firm retains Hewitt and no other specialist consultant, and in the following period retains Meridian as a compensation consultant; or

c) the firm retains Mercer and no other specialist consultant, and in the following period retains Compensation Advisory Partners as a compensation consultant.

This variable is calculated every fiscal year from 2009, and rolled such that once a firm switches to a related specialist consultant, this variable $=1$ in every subsequent fiscal year.

A firm is defined as staying with the same multiservice consultant if it retains the same multiservice consultant in a given fiscal year from 2009 onwards as it did in 2008 (including predecessor firms). For example, if a firm retained Mercer and no other specialist consultants in 2008, and in 2009 retained Mercer and no other specialist consultants, it would be classified as staying with the same multiservice consultant.

This variable is calculated every fiscal year from 2009, and rolled such that once a firm no longer meets the above criteria, the variable switches to zero and stays at zero in every subsequent fiscal year. 


\section{Appendix II. Data Definitions.}

\section{$\underline{\text { Firm characteristics }}$}

Log (Market capitalization) is the natural logarithm of market capitalization at the beginning of the fiscal year.

Book-to-market is the book value of equity divided by market value of equity at the beginning of the fiscal year.

$R O A$ is net income divided by end-of-year total assets for the prior fiscal year.

$\triangle R O A$ is equal to ROA from this fiscal year minus ROA from the previous fiscal year.

Stock return ( $t$-1) is the stock price return over the previous fiscal year. Stock return $(t-2)$ is the stock price return over the fiscal year two periods ago.

Log (\# business segments) is the natural logarithm of the number of business segments or operating segments in Compustat with positive, non-missing revenue.

Asset growth is the natural logarithm of total assets divided by prior year total assets.

Employee growth is the natural logarithm of number of employees divided by prior year number of employees.

\section{Compensation characteristics}

Total compensation is the TDC1 variable from ExecuComp for the current fiscal year.

Non-incentive compensation is total compensation minus cash-incentive and equity-based pay from ExecuComp, for the current fiscal year.

Cash incentive compensation is the sum of non-equity incentives and bonus, from ExecuComp for the current fiscal year.

Equity compensation is the sum of the fair value of option awards and stock awards, from ExecuComp for the current fiscal year.

Proportion Incentive Pay is long-term incentive pay (TDC1 - salary - bonus) as a proportion of total compensation.

Proportion Equity Pay is CEO's equity incentive pay as a proportion of total compensation.

Options as a \% of Equity Pay is CEO's option-based compensation as a proportion of total equity (option + equity) compensation.

Log (firm-related wealth) is the natural logarithm of the value of the CEO's stock and option portfolio, calculated as per Daniel, Li, and Naveen (2013).

CEO Deferred Comp (\% of Total Comp) is the firm's contribution to CEO's deferred compensation plans as a proportion of total compensation.

CEO Options (\% of Firm's Total Option Exp.) is the CEO's Option Compensation as a proportion of the firm's total option expense (i.e., value of options paid to all employees).

Top 5 Exec Options (\% of Firm's Total Option Exp.) is the sum of option Compensation paid to top 5 executives as a proportion of the firm's total option expense (i.e., value of options paid to all employees). 
Log (CEO's Options Avg. Remaining Vesting Period) is the natural logarithm of the average remaining vesting period of the CEO's options held.

\section{CEO characteristics}

Founder $C E O$ is a dummy variable equal to one if the CEO is the founder of the firm.

CEO age is the CEO's age in years.

CEO tenure is the number of years the CEO has been in his current role.

New $C E O$ is a dummy variable equal to one if there was a change in CEO during the fiscal year.

\section{Ownership characteristics}

Institutional ownership is the percentage of outstanding shares held by institutions at the end of the prior fiscal year.

Block holder is the number of institutions with 5\% or more ownership of outstanding shares at the end of the prior fiscal year.

\section{$\underline{\text { Board characteristics }}$}

$\%$ independent board is the proportion of board members who are independent.

Board size is equal to the number of board members.

$\%$ board busy is the percentage of board members who serve on another board.

$\%$ board old is the percentage of board members who are at least 69 years old.

CEO is Chairman is a dummy variable equal to one if the CEO is also Chairman of the Board.

Dual class shares is equal to one if the firm has multiple classes of shares according to RiskMetrics and zero otherwise.

Staggered board is equal to one if board members' terms are staggered according to RiskMetrics and zero otherwise.

\% board appointed by CEO is the percentage of board members who have joined since the CEO's tenure at the firm.

\section{Compensation committee characteristics}

Comp. committee \% busy, \% old, and size are the percentage of busy and old (described above) members of the compensation committee, and the number of board members in the compensation committee. 
Table 1. Benefits and Costs Analysis for Switching Compensation Consultants.

\begin{tabular}{|c|c|c|c|c|c|}
\hline & Benefits & Costs & $\begin{array}{l}\text { Choice } \\
\text { made } \\
\text { by }\end{array}$ & Type of firm & $\begin{array}{l}\text { Variables of } \\
\text { interest }\end{array}$ \\
\hline $\begin{array}{l}\text { Switch to related } \\
\text { spin-off }\end{array}$ & $\begin{array}{l}\text { Benefit for CEO: No fee } \\
\text { disclosure: No need to disclose fees } \\
\text { for any compensation consulting } \\
\text { services (executive or other). } \\
\text { Benefit for CEO: Appearance of } \\
\text { independence: Give the appearance } \\
\text { of independence in seeking } \\
\text { executive compensation advice } \\
\text { Benefit for CEO: Maintain } \\
\text { relationship: Retain executive } \\
\text { compensation consultant partner } \\
\text { with existing relationship that left } \\
\text { for spin-off firm; may still be able } \\
\text { to influence executive } \\
\text { compensation recommendation with } \\
\text { contracts for other services. } \\
\text { Benefit for board: Compensation } \\
\text { consultant is familiar with firm } \\
\text { Benefit for board if under CEO } \\
\text { influence: Appearance of } \\
\text { independence }\end{array}$ & $\begin{array}{l}\text { - Cost for CEO: None } \\
\text { - Cost for board: May lose cross- } \\
\text { learning and efficiency benefits } \\
\text { from having all HR related } \\
\text { services provided by one main } \\
\text { consultant }\end{array}$ & $\mathrm{CEO}$ & $\begin{array}{l}\text { Weak } \\
\text { corporate } \\
\text { governance } \\
\text { Likely to } \\
\text { be prone to } \\
\text { agency } \\
\text { problems }\end{array}$ & $\begin{array}{l}\text { Corporate } \\
\text { governance } \\
\text { variables } \\
\text { CEO power } \\
\text { variables } \\
\text { - Incentive } \\
\text { compensation } \\
\text { variables } \\
\text { Other pay } \\
\text { variables }\end{array}$ \\
\hline $\begin{array}{l}\text { Switch to unrelated } \\
\text { specialist }\end{array}$ & $\begin{array}{l}\text { Benefits for CEO: No fee } \\
\text { disclosure: No need to disclose fees } \\
\text { for any compensation consulting } \\
\text { services (executive or other). } \\
\text { Benefits for board: Independent } \\
\text { advice: New compensation } \\
\text { consultant partner, cross-selling not } \\
\text { possible. }\end{array}$ & $\begin{array}{l}\text { Cost for CEO: Need to influence } \\
\text { new compensation consultant } \\
\text { partner. Have no access to cross- } \\
\text { selling incentives for increasing } \\
\text { influence } \\
\text { Cost for board: May lose cross- } \\
\text { learning and efficiency benefits } \\
\text { from having all HR related } \\
\text { services provided by one main } \\
\text { consultant }\end{array}$ & Board & $\begin{array}{l}\text { Potentially } \\
\text { fewer agency } \\
\text { problems }\end{array}$ & $\begin{array}{l}\text { Variables above } \\
\text { and firm } \\
\text { characteristics }\end{array}$ \\
\hline
\end{tabular}


- Benefit for CEO: None

consultant

- Benefit for board: Keep crosslearning and efficiency benefits from having all HR related services provided by one main consultant

- Benefit for board: Full disclosure of compensation to consultant suggests transparency
- Cost for CEO: Lose relationship Board

with executive compensation

consultant partner with existing

relationship that left for spin-off

firm

- Cost for CEO: Increased

transparency: Fee disclosure

- Cost for board: Lose appearance

of independence in seeking

executive compensation advice 
Table 2. Sample composition

The sample is comprised of the intersection of firms in the Incentive Lab executive compensation database and in ExecuComp. A firm is recorded as using a compensation consultant in a given fiscal year if the firm has an associated compensation consultant in the Incentive Lab dataset. A firm is recorded as starting to use a compensation consultant if it uses a consultant in the current year, and did not in the previous year. A firm is recorded as changing compensation consultant if it adds, drops, or swaps a consultant, with respect to the previous year.

\begin{tabular}{|c|c|c|c|c|c|c|c|c|}
\hline Panel A: Sample composition by year & $2006^{1}$ & 2007 & 2008 & 2009 & 2010 & 2011 & 2012 & All \\
\hline Firm uses compensation consultant & 688 & 869 & 863 & 840 & 840 & 818 & 774 & 5,692 \\
\hline Firm does not use compensation consultant & 76 & 90 & 85 & 96 & 83 & 68 & 51 & 549 \\
\hline Total firms & 764 & 959 & 948 & 936 & 923 & 886 & 825 & 6,241 \\
\hline$\%$ firms with consultants & $90.1 \%$ & $90.6 \%$ & $91.0 \%$ & $89.7 \%$ & $91.0 \%$ & $92.3 \%$ & $93.8 \%$ & $91.2 \%$ \\
\hline$\%$ firms that start using a consultant ${ }^{2}$ & & $43.4 \%$ & $25.6 \%$ & $27.1 \%$ & $26.0 \%$ & $24.1 \%$ & $25.0 \%$ & $28.3 \%$ \\
\hline$\%$ firms that change consultant ${ }^{3}$ & & $30.6 \%$ & $27.7 \%$ & $33.2 \%$ & $39.6 \%$ & $27.1 \%$ & $18.0 \%$ & $29.5 \%$ \\
\hline
\end{tabular}

\begin{tabular}{|c|c|c|c|c|}
\hline \multirow{2}{*}{$\begin{array}{l}\text { Panel B: Sample composition by industry } \\
\text { Consumer non-durables }\end{array}$} & \multicolumn{2}{|c|}{ Consultant used } & \multicolumn{2}{|c|}{ No consultant used } \\
\hline & 363 & $6.4 \%$ & 20 & $3.6 \%$ \\
\hline Consumer durables & 97 & $1.7 \%$ & 17 & $3.1 \%$ \\
\hline Manufacturing & 674 & $11.8 \%$ & 38 & $6.9 \%$ \\
\hline Energy & 303 & $5.3 \%$ & 24 & $4.4 \%$ \\
\hline Chemicals & 194 & $3.4 \%$ & - & $0.0 \%$ \\
\hline Business equipment & 935 & $16.4 \%$ & 136 & $24.8 \%$ \\
\hline Telecoms & 174 & $3.1 \%$ & 26 & $4.7 \%$ \\
\hline Utilities & 368 & $6.5 \%$ & 1 & $0.2 \%$ \\
\hline Wholesale \& retail & 532 & $9.3 \%$ & 86 & $15.7 \%$ \\
\hline Healthcare & 413 & $7.3 \%$ & 9 & $1.6 \%$ \\
\hline Financial & 1,021 & $17.9 \%$ & 125 & $22.8 \%$ \\
\hline \multirow[t]{2}{*}{ Other } & 618 & $10.9 \%$ & 67 & $12.2 \%$ \\
\hline & 5,692 & $100 \%$ & 549 & $100 \%$ \\
\hline
\end{tabular}

(1) Our 2006 sample excludes firms with a fiscal year end before December - SEC executive pay rules requiring disclosure of compensation consultants came into force for fiscal years ending on or after 15 December 2006.

(2) As a percentage of firms which did not use a consultant in the previous fiscal year.

(3) As a percentage of firms which use a consultant in the current and previous fiscal year.

(4) Industry definitions are based on 12 Industry Portfolios from Ken French's website. 


\section{Table 3. Compensation consultant market share}

This table reports compensation consultant market share based on number of clients, for each fiscal year from 2006 to 2012. Multiservice firms are denoted by M. Specialist compensation consulting firms are denoted by S. Specialist firms that were spun-off by a multiservice parent are denoted by*. Firms are ordered by market share in 2006 .

\begin{tabular}{|c|c|c|c|c|c|c|c|c|}
\hline \multicolumn{2}{|l|}{ Panel A: Compensation consulting industry statistics } & 2006 & 2007 & 2008 & 2009 & 2010 & 2011 & 2012 \\
\hline \multicolumn{2}{|l|}{ Number of compensation consultants } & 85 & 103 & 80 & 78 & 75 & 73 & 67 \\
\hline \multicolumn{2}{|l|}{ Herfindahl index of market share } & 0.113 & 0.108 & 0.108 & 0.092 & 0.083 & 0.082 & 0.086 \\
\hline \multicolumn{2}{|l|}{ Market share of specialist consultants } & $35.4 \%$ & $39.6 \%$ & $41.3 \%$ & $44.3 \%$ & $59.3 \%$ & $69.0 \%$ & $70.4 \%$ \\
\hline \multicolumn{2}{|l|}{ Market share of multiservice consultants } & $64.6 \%$ & $60.4 \%$ & $58.7 \%$ & $55.7 \%$ & $40.7 \%$ & $31.0 \%$ & $29.6 \%$ \\
\hline Panel B: Top 15 Firms & & 2006 & 2007 & 2008 & 2009 & 2010 & 2011 & 2012 \\
\hline Towers Watson \& predecessors ${ }^{1}$ & $\mathrm{M}$ & $26.7 \%$ & $25.7 \%$ & $24.9 \%$ & $23.6 \%$ & $17.0 \%$ & $11.8 \%$ & $10.9 \%$ \\
\hline Pay Governance & $*$ & & & & $0.2 \%$ & $6.7 \%$ & $8.6 \%$ & $8.8 \%$ \\
\hline Aon Hewitt, associated co's and predecessors ${ }^{2}$ & M & $16.5 \%$ & $15.7 \%$ & $16.5 \%$ & $16.4 \%$ & $10.3 \%$ & $7.6 \%$ & $7.3 \%$ \\
\hline Meridian & $*$ & & & & $0.4 \%$ & $6.4 \%$ & $8.1 \%$ & $8.9 \%$ \\
\hline Frederic W. Cook & $\mathrm{S}$ & $15.6 \%$ & $16.8 \%$ & $18.5 \%$ & $16.7 \%$ & $16.5 \%$ & $18.7 \%$ & $19.7 \%$ \\
\hline Mercer & M & $14.8 \%$ & $13.3 \%$ & $11.7 \%$ & $10.2 \%$ & $8.3 \%$ & $6.8 \%$ & $6.7 \%$ \\
\hline Compensation Advisory Partners & $*$ & & & & $1.1 \%$ & $1.8 \%$ & $2.6 \%$ & $2.6 \%$ \\
\hline Pearl Meyer & $\mathrm{S}$ & $5.5 \%$ & $5.5 \%$ & $4.8 \%$ & $5.3 \%$ & $6.6 \%$ & $7.7 \%$ & $8.0 \%$ \\
\hline Hay Group & M & $2.4 \%$ & $2.0 \%$ & $2.1 \%$ & $2.0 \%$ & $2.0 \%$ & $2.5 \%$ & $2.1 \%$ \\
\hline Compensia & $\mathrm{S}$ & $1.8 \%$ & $2.6 \%$ & $2.6 \%$ & $3.5 \%$ & $4.0 \%$ & $4.3 \%$ & $4.1 \%$ \\
\hline Deloitte & M & $1.7 \%$ & $1.6 \%$ & $1.6 \%$ & $1.6 \%$ & $1.4 \%$ & $1.0 \%$ & $1.0 \%$ \\
\hline Semler Brossy & $\mathrm{S}$ & $1.7 \%$ & $2.2 \%$ & $3.2 \%$ & $3.4 \%$ & $3.1 \%$ & $3.4 \%$ & $3.8 \%$ \\
\hline Buck Consultants & M & $0.9 \%$ & $0.4 \%$ & $0.2 \%$ & $0.3 \%$ & $0.4 \%$ & $0.3 \%$ & $0.3 \%$ \\
\hline PricewaterhouseCoopers & M & $0.8 \%$ & $1.1 \%$ & $0.7 \%$ & $0.6 \%$ & $0.4 \%$ & $0.3 \%$ & $0.4 \%$ \\
\hline Ernst \& Young & M & $0.7 \%$ & $0.6 \%$ & $0.7 \%$ & $0.6 \%$ & $0.4 \%$ & $0.3 \%$ & $0.4 \%$ \\
\hline Total & & $89.1 \%$ & $87.4 \%$ & $87.6 \%$ & $85.9 \%$ & $85.6 \%$ & $84.0 \%$ & $85.2 \%$ \\
\hline
\end{tabular}

(1) Includes Towers Perrin, Watson Wyatt, and Towers Watson.

(2) Includes Hewitt \& Associates, Aon, Aon Hewitt, Radford, and McLagan. 


\section{Table 4. Compensation consultant switching behavior and fees disclosure in response to 2009 rule change.}

Panel A. This panel reports the evolution of compensation consultant use and switching behavior after the disclosure rule change. Panel A1 shows firms that used one multiservice compensation consultant in 2008. From 2009 onwards, we calculate the percentage of firms that (a) stay with the same consultant, (b) switch to another multiservice consultant, (c) switch to an unrelated specialist compensation consultant, (d) switch to a related spin-off consultant (e.g. from Towers Watson to Pay Governance), and (e) switch to an unrelated spin-off (e.g. to Pay Governance, from Mercer). Panel A2 shows firm that used one specialist compensation consultant in 2008. From 2009 onwards, we calculate the percentage of firms that (a) continue to use an unrelated specialist consultant, (b) switch to a multiservice consultant, and (c) switch to one of the new spin-off specialist compensation consultants.

\begin{tabular}{lrrrr}
\hline & 2009 & 2010 & 2011 & 2012 \\
\hline Panel A1: Firm uses one multiservice consultant in 2008 $(n=453)$ & & & & \\
Stay with same multiservice consultant & $71.1 \%$ & $35.5 \%$ & $29.3 \%$ & $27.2 \%$ \\
Switch to another multiservice consultant & $2.0 \%$ & $0.9 \%$ & $2.7 \%$ & $5.3 \%$ \\
Switch to unrelated pre-existing specialist & $12.4 \%$ & $25.1 \%$ & $27.9 \%$ & $29.3 \%$ \\
Switch to related spun-off specialist & $3.1 \%$ & $25.6 \%$ & $27.1 \%$ & $26.8 \%$ \\
Switch to unrelated spun-off specialist & $0.2 \%$ & $3.2 \%$ & $5.4 \%$ & $6.8 \%$ \\
Other (e.g. specialist AND multiservice) & $11.3 \%$ & $9.7 \%$ & $7.6 \%$ & $4.6 \%$ \\
& & & & \\
Panel A2: Firm uses one specialist consultant in 2008 (n=301) & & & & \\
Stay with / switch to another unrelated specialist & $88.0 \%$ & $81.8 \%$ & $80.6 \%$ & $78.5 \%$ \\
Switch to a multiservice consultant & $2.7 \%$ & $1.7 \%$ & $3.2 \%$ & $3.6 \%$ \\
Switch to a spun-off specialist & $0.0 \%$ & $0.0 \%$ & $0.4 \%$ & $2.6 \%$ \\
Other (e.g. specialist AND multiservice) & $9.3 \%$ & $16.4 \%$ & $15.8 \%$ & $15.3 \%$ \\
\hline
\end{tabular}

Panel B. This panel shows disclosed fees for executive compensation consulting services (CC) and for other non-executive compensation services (Other). The data include fiscal years from 2009 onwards after the SEC disclosure rule change was effected for multiservice consultant client firms.

\begin{tabular}{lrrrrrr}
\hline Fees reported: & $\mathrm{N}$ & Mean & Median & St. Dev. & Min. & Max. \\
\hline CC Fees & 415 & 170,119 & 135,380 & 144,925 & 6,400 & $1,049,500$ \\
Other Fees & & $1,512,441$ & 600,435 & $2,415,137$ & 2,879 & $14,928,178$ \\
\hline
\end{tabular}




\section{Table 5. Full sample descriptive statistics.}

Panel A shows the summary statistics for two groups: firm-years that use a compensation consultant and firm-years that do not use a compensation consultant. The sample spans a period from 2006 to 2012. Panel B shows statistics for the sample from 2009 onwards (after the disclosure change) for firms that used a multiservice consultant before 2009 and continued to use a multiservice consultant (1), compared to those that switched to a related spin-off specialist consultant (2).*, **, and *** represent significance at the $10 \%, 5 \%$, and $1 \%$ levels, respectively, for a Kruskall-Wallis test between (1) and (2). The variables are defined in Appendix II.

Panel A: Full Sample

\begin{tabular}{|c|c|c|c|c|c|c|c|}
\hline \multirow[b]{2}{*}{ Variables } & \multicolumn{3}{|c|}{ Consultant } & \multicolumn{3}{|c|}{ No consultant } & \multirow{2}{*}{$\begin{array}{r}\text { Kruskal- } \\
\text { Wallis } \\
\text { p-value }\end{array}$} \\
\hline & Mean & Median & Std. Dev. & Mean & Median & $\begin{array}{l}\text { Std. } \\
\text { Dev. }\end{array}$ & \\
\hline \multicolumn{8}{|l|}{ Firm characteristics } \\
\hline Log (Market capitalization) & 8.560 & 8.406 & 1.309 & 8.217 & 8.156 & 1.479 & 0.000 \\
\hline Book-to-market & 0.524 & 0.440 & 1.072 & 0.587 & 0.464 & 0.611 & 0.285 \\
\hline ROA & 0.095 & 0.086 & 0.092 & 0.100 & 0.082 & 0.112 & 0.489 \\
\hline$\Delta \mathrm{ROA}(\mathrm{t}-1)$ & 0.000 & 0.002 & 0.055 & -0.003 & -0.001 & 0.069 & 0.045 \\
\hline Stock return $(\mathrm{t}-1)$ & 0.129 & 0.083 & 0.692 & 0.136 & 0.060 & 0.587 & 0.924 \\
\hline Stock return $(\mathrm{t}-2)$ & 0.179 & 0.104 & 1.097 & 0.144 & 0.081 & 0.565 & 0.212 \\
\hline Log (\# business segments) & 2.500 & 2.708 & 0.861 & 2.457 & 2.485 & 0.756 & 0.009 \\
\hline Asset growth (t-1) & 0.075 & 0.051 & 0.222 & 0.079 & 0.064 & 0.224 & 0.051 \\
\hline Employee growth (t-1) & 0.030 & 0.020 & 0.198 & 0.042 & 0.039 & 0.192 & 0.004 \\
\hline \multicolumn{8}{|l|}{ CEO characteristics } \\
\hline Total compensation & 8.202 & 6.156 & 8.204 & 4.985 & 2.996 & 7.470 & 0.000 \\
\hline Non-incentive compensation & 1.370 & 1.089 & 2.017 & 0.922 & 0.815 & 0.638 & 0.000 \\
\hline Cash incentive compensation & 1.999 & 1.319 & 2.958 & 1.417 & 0.640 & 3.735 & 0.000 \\
\hline $\begin{array}{l}\text { Equity incentive } \\
\text { compensation }\end{array}$ & 4.832 & 3.408 & 6.025 & 2.644 & 0.882 & 4.770 & 0.000 \\
\hline Proportion incentive pay (t-1) & 0.743 & 0.815 & 0.206 & 0.619 & 0.708 & 0.292 & 0.000 \\
\hline Log (firm-related wealth) & 9.768 & 9.971 & 2.210 & 10.033 & 10.361 & 3.093 & 0.000 \\
\hline Founder CEO & 0.019 & 0.000 & 0.136 & 0.109 & 0.000 & 0.312 & 0.000 \\
\hline CEO age & 55.693 & 56.000 & 6.434 & 55.927 & 55.000 & 8.584 & 0.627 \\
\hline CEO tenure & 6.335 & 5.000 & 6.142 & 10.126 & 7.000 & 9.387 & 0.000 \\
\hline New CEO & 0.109 & 0.000 & 0.311 & 0.098 & 0.000 & 0.298 & 0.439 \\
\hline \multicolumn{8}{|l|}{ Ownership Characteristics } \\
\hline Institutional ownership & 0.746 & 0.816 & 0.276 & 0.731 & 0.806 & 0.296 & 0.516 \\
\hline Block holders & 1.637 & 1.000 & 1.745 & 1.661 & 1.000 & 1.785 & 0.688 \\
\hline \multicolumn{8}{|l|}{ Board Characteristics } \\
\hline$\%$ independent board & 0.795 & 0.800 & 0.102 & 0.733 & 0.750 & 0.106 & 0.000 \\
\hline Log (Board size) & 2.299 & 2.303 & 0.204 & 2.175 & 2.197 & 0.220 & 0.000 \\
\hline$\%$ board busy & 0.570 & 0.566 & 0.197 & 0.465 & 0.523 & 0.209 & 0.000 \\
\hline$\%$ board old & 0.215 & 0.200 & 0.143 & 0.249 & 0.217 & 0.168 & 0.000 \\
\hline CEO is Chairman & 0.677 & 1.000 & 0.468 & 0.670 & 1.000 & 0.471 & 0.738 \\
\hline Dual class shares & 0.056 & 0.000 & 0.230 & 0.089 & 0.000 & 0.285 & 0.002 \\
\hline Staggered board & 0.403 & 0.000 & 0.491 & 0.292 & 0.000 & 0.455 & 0.000 \\
\hline$\%$ board appointed by CEO & 0.498 & 0.500 & 0.382 & 0.490 & 0.500 & 0.424 & 0.890 \\
\hline
\end{tabular}


Compensation Committee Characteristics

Comp. committee - $\%$ busy

0.622

0.615

0.253

0.515

0.613

0.272

0.000

Comp. committee - $\%$ old

0.252

0.250

0.219

0.302

0.270

0.238

0.000

Log (Comp. committee size)

$1.320 \quad 1.335$

0.252

1.215

1.249

0.238

0.000 


\begin{tabular}{|c|c|c|c|c|c|}
\hline \multirow[b]{3}{*}{ Variables } & \multicolumn{2}{|c|}{ (1) } & \multicolumn{2}{|c|}{ (2) } & \multirow{3}{*}{$\begin{array}{c}\text { Significance } \\
\text { of } \\
\text { differences } \\
\text { in Medians }\end{array}$} \\
\hline & \multicolumn{2}{|c|}{$\begin{array}{c}\text { Stay with } \\
\text { Multiservice }\end{array}$} & \multicolumn{2}{|c|}{$\begin{array}{l}\text { Switch to Related } \\
\text { Specialist }\end{array}$} & \\
\hline & Mean & Median & Mean & Median & \\
\hline Number of observations & \multicolumn{2}{|c|}{705} & \multicolumn{2}{|c|}{361} & \\
\hline \multicolumn{6}{|l|}{ Firm characteristics } \\
\hline Log (Market cap.) & 8.241 & 8.114 & 8.795 & 8.777 & $* * *$ \\
\hline Book-to-market & 0.667 & 0.547 & 0.703 & 0.503 & \\
\hline ROA & 0.093 & 0.088 & 0.082 & 0.078 & $* *$ \\
\hline$\triangle \mathrm{ROA}(\mathrm{t}-1)$ & -0.002 & 0.001 & 0.004 & 0.003 & \\
\hline Stock return $(\mathrm{t}-1)$ & -0.010 & -0.082 & 0.337 & 0.162 & $* * *$ \\
\hline Stock return $(\mathrm{t}-2)$ & 0.118 & 0.033 & 0.206 & 0.069 & \\
\hline Log (\# business segments) & 2.479 & 2.708 & 2.247 & 2.398 & $* * *$ \\
\hline Asset growth (t-1) & 0.038 & 0.027 & 0.038 & 0.043 & $*$ \\
\hline Employee growth (t-1) & 0.003 & 0.004 & -0.008 & 0.000 & \\
\hline \multicolumn{6}{|l|}{ CEO characteristics } \\
\hline Total compensation & 6.964 & 5.813 & 9.523 & 7.632 & *** \\
\hline Non-incentive comp. & 1.339 & 1.061 & 1.482 & 1.211 & $* * *$ \\
\hline Cash incentive comp. & 1.744 & 1.307 & 2.521 & 1.838 & $* * *$ \\
\hline Equity incentive comp. & 3.879 & 3.140 & 5.530 & 4.169 & $* * *$ \\
\hline Proportion incentive pay & 0.757 & 0.823 & 0.803 & 0.842 & $* * *$ \\
\hline Log (firm-related wealth) & 9.953 & 9.887 & 9.985 & 10.092 & $*$ \\
\hline Founder CEO & 0.007 & 0.000 & 0.008 & 0.000 & \\
\hline CEO age & 56.287 & 56.000 & 56.967 & 57.000 & $* *$ \\
\hline CEO tenure & 7.214 & 5.000 & 6.180 & 4.000 & $* *$ \\
\hline New CEO & 0.104 & 0.000 & 0.136 & 0.000 & \\
\hline \multicolumn{6}{|l|}{ Ownership Characteristics } \\
\hline Institutional ownership & 0.784 & 0.845 & 0.765 & 0.800 & $* * *$ \\
\hline Block holders & 2.020 & 2.000 & 1.872 & 1.000 & \\
\hline \multicolumn{6}{|l|}{ Board Characteristics } \\
\hline$\%$ independent board & 0.795 & 0.809 & 0.817 & 0.833 & $* * *$ \\
\hline Log (Board size) & 2.291 & 2.303 & 2.359 & 2.313 & $* * *$ \\
\hline$\%$ board busy & 0.550 & 0.563 & 0.596 & 0.600 & $* * *$ \\
\hline$\%$ board old & 0.220 & 0.204 & 0.247 & 0.243 & $* * *$ \\
\hline CEO is Chairman & 0.672 & 1.000 & 0.654 & 1.000 & \\
\hline Dual class shares & 0.050 & 0.000 & 0.039 & 0.000 & \\
\hline Staggered board & 0.421 & 0.000 & 0.388 & 0.000 & \\
\hline$\%$ board appointed by CEO & 0.455 & 0.429 & 0.473 & 0.500 & \\
\hline \multicolumn{6}{|c|}{ Compensation Committee Characteristics } \\
\hline Comp. committee - \% busy & 0.599 & 0.615 & 0.652 & 0.667 & $* * *$ \\
\hline Comp. committee - $\%$ old & 0.265 & 0.250 & 0.281 & 0.261 & $*$ \\
\hline Log (Comp. committee size) & 1.347 & 1.386 & 1.369 & 1.386 & \\
\hline
\end{tabular}




\section{Table 6. Determinants of compensation consultant usage and switching behaviour.}

This table reports coefficients from logistic regressions. The dependent variables are: (1) whether a firm uses a compensation consultant in the current year; (2) whether a firm with a multiservice compensation consultant switches to a related spin-off specialist after 2009; (3) whether a firm with a multiservice compensation consultant switches to a related spin-off specialist after 2009 (coded 0), or switches to an unrelated specialist after 2009 (coded 1), or stays with the multiservice consultant (coded 2). The coefficients shown for binomial regressions (1) and (2) are associated with a higher likelihood of the consultant usage or switching behaviour. The coefficients shown for ordered logit regression (3) are associated with a higher likelihood of higher coded choices, i.e., a lower likelihood of switching to a related spun-off consultant. All variables are as defined in Appendix II. The p-value for the logistic regression z-statistic is shown in parentheses. *, **, and *** represent significance at the $10 \%, 5 \%$, and $1 \%$ levels, respectively.

\begin{tabular}{|c|c|c|c|c|c|c|}
\hline & $\begin{array}{r}\text { Firm uses } \\
\text { consultant } \\
(1)\end{array}$ & & $\begin{array}{l}\text { Firm switches } \\
\text { to related spin- } \\
\text { off from multi- } \\
\text { service (2) }\end{array}$ & & $\begin{array}{r}\text { Ordered logit: } \\
\text { Firm switches to } \\
\text { related spinoff } \\
\text { (baseline), } \\
\text { switches to } \\
\text { unrelated spinoff, } \\
\text { or stays with } \\
\text { multiservice (3) }\end{array}$ & \\
\hline \multirow[t]{2}{*}{ Log (Market capitalization) } & -0.02 & & 0.21 & $* *$ & -0.19 & $* * *$ \\
\hline & $(0.71)$ & & $(0.03)$ & & $(0.01)$ & \\
\hline \multirow[t]{2}{*}{ Book-to-market } & -0.09 & & 0.38 & $* * *$ & -0.25 & $* * *$ \\
\hline & $(0.16)$ & & $(0.01)$ & & $(0.01)$ & \\
\hline \multirow[t]{2}{*}{ ROA } & -1.70 & $* * *$ & -3.03 & $* *$ & 0.77 & \\
\hline & $(0.01)$ & & $(0.02)$ & & $(0.30)$ & \\
\hline \multirow[t]{2}{*}{$\triangle \mathrm{ROA}$} & 1.59 & & 2.19 & & -1.69 & \\
\hline & $(0.10)$ & & $(0.19)$ & & $(0.16)$ & \\
\hline \multirow[t]{2}{*}{ Stock return $(\mathrm{t}-1)$} & 0.00 & & 0.09 & & -0.10 & \\
\hline & $(0.95)$ & & $(0.25)$ & & $(0.12)$ & \\
\hline \multirow[t]{2}{*}{ Stock return $(\mathrm{t}-2)$} & 0.02 & & 0.05 & & -0.05 & \\
\hline & $(0.64)$ & & $(0.45)$ & & $(0.35)$ & \\
\hline \multirow[t]{2}{*}{ Log (\# business segments) } & -0.06 & & -0.15 & & 0.15 & $*$ \\
\hline & $(0.43)$ & & $(0.22)$ & & $(0.08)$ & \\
\hline \multirow[t]{2}{*}{ Employee growth (t-1) } & 0.00 & & -0.97 & $*$ & 0.60 & $*$ \\
\hline & $(0.99)$ & & $(0.06)$ & & $(0.09)$ & \\
\hline \multirow[t]{2}{*}{ Proportion incentive pay } & 1.47 & $* * *$ & 1.32 & $* *$ & -0.89 & $* *$ \\
\hline & $(0.00)$ & & $(0.02)$ & & $(0.02)$ & \\
\hline \multirow[t]{2}{*}{ Log (firm-related wealth) } & -0.07 & $* * *$ & -0.01 & & 0.04 & \\
\hline & $(0.01)$ & & $(0.93)$ & & $(0.44)$ & \\
\hline \multirow[t]{2}{*}{ Founder CEO } & -1.16 & $* * *$ & -0.46 & & 0.45 & \\
\hline & $(0.00)$ & & $(0.57)$ & & $(0.53)$ & \\
\hline \multirow[t]{2}{*}{ CEO age } & 0.00 & & -0.02 & & 0.02 & $*$ \\
\hline & $(0.94)$ & & $(0.14)$ & & $(0.09)$ & \\
\hline \multirow[t]{2}{*}{ CEO tenure } & -0.04 & $* * *$ & -0.02 & & 0.02 & \\
\hline & $(0.00)$ & & $(0.17)$ & & $(0.11)$ & \\
\hline
\end{tabular}


New CEO

$\log$ board size

$\%$ independent board

CEO is Chairman

Dual class shares

Staggered board

$\%$ board appointed by CEO

Institutional ownership

Block holders

Compensation committee - \% busy

Compensation committee - \% old

Log (compensation committee size)

Industry-fixed effects

Year-fixed effects

Sample size

Pseudo-R ${ }^{2}$
$-0.27$

$(0.18)$

$0.89 * * *$

$(0.00)$

$1.08 * *$

$(0.03)$

0.04

$(0.72)$

$-0.43$

$(0.04)$

$0.75 * * *$

$(0.00)$

$0.27 *$

(0.07)

$-0.17$

(0.39)

$-0.01$

(0.72)

$1.20 * * *$

(0.00)

$-0.73 * * *$

(0.00)

0.18

(0.42)

Yes

Yes

5,952

0.599
$-0.10$

(0.71)

0.58

(0.18)

$-1.12$

(0.20)

0.06

(0.77)

$-0.04$

(0.92)

0.18

(0.30)

0.13

(0.59)

$-0.79 * *$

(0.04)

0.00

(0.98)

$0.91 * * *$

(0.01)

$-0.47$

(0.18)

$-0.48$

(0.20)

Yes

Yes

1,040

0.367
0.09

(0.64)

$-0.59 * *$

(0.04)

0.57

(0.33)

$-0.04$

(0.74)

0.14

(0.65)

$-0.13$

(0.27)

$-0.02$

(0.93)

$0.50 *$

(0.06)

0.00

(0.90)

$-0.56 * *$

(0.02)

0.27

(0.26)

0.31

(0.24)

Yes

Yes

1,364

0.255 


\section{Table 7. Matched-pairs analysis of pay levels and consultant usage}

This table reports the difference in compensation levels for matched-pairs of firm-years, where one firm uses a compensation consultant and the other firm does not. Matching is based on propensity scores using 1:1 caliper matching. Matching is based on the propensity to hire a compensation consultant from firm, CEO, and governance characteristics (explanatory variables shown in Table 6). All variables are as defined in Appendix II. Panel A shows the covariates for firms that use consultants (treatment) and firms that do not use consultants (control), as well as p values for t-tests and Kolmogorov-Smirnov tests for differences between the two samples, using Firm, CEO, and governance characteristics for matching. Panel B shows the mean and median differences, which are measured as the compensation level for a firm that uses a compensation consultant, minus the level for a matched firm that does not use a consultant.

\begin{tabular}{lcccccc}
\hline Panel A: Covariates & $\begin{array}{c}\text { Mean } \\
\text { treatment }\end{array}$ & $\begin{array}{c}\text { Mean } \\
\text { control }\end{array}$ & $\begin{array}{c}\text { Median } \\
\text { treatment }\end{array}$ & $\begin{array}{c}\text { Median } \\
\text { control }\end{array}$ & $\begin{array}{c}\text { t-stat } \\
\text { p value }\end{array}$ & $\begin{array}{c}\text { K-S } \\
\text { palue }\end{array}$ \\
\hline Log (Market capitalization) & 8.290 & 8.292 & 8.172 & 8.238 & 0.988 & 0.901 \\
Book-to-market & 0.525 & 0.569 & 0.437 & 0.470 & 0.988 & 0.348 \\
ROA & 0.098 & 0.099 & 0.084 & 0.089 & 0.396 & 0.834 \\
AROA (t-1) & 0.002 & -0.002 & 0.002 & 0.000 & 0.396 & 0.581 \\
Stock return (t-1) & 0.203 & 0.147 & 0.095 & 0.098 & 0.877 & 0.834 \\
Stock return (t-2) & 0.287 & 0.199 & 0.117 & 0.149 & 0.877 & 0.286 \\
Log (\# business segments) & 2.441 & 2.414 & 2.565 & 2.639 & 0.466 & 0.901 \\
Employee growth (t-1) & 0.039 & 0.050 & 0.032 & 0.051 & 0.466 & 0.116 \\
Proportion incentive pay & 0.743 & 0.739 & 0.802 & 0.796 & 0.275 & 0.668 \\
Log (firm-related wealth) & 9.968 & 9.988 & 10.224 & 10.257 & 0.276 & 0.951 \\
Founder CEO & 0.016 & 0.016 & 0.000 & 0.000 & 0.579 & 1.000 \\
CEO age & 55.102 & 54.884 & 55.368 & 55.000 & 0.579 & 0.999 \\
CEO tenure & 7.156 & 7.544 & 6.000 & 6.500 & 0.760 & 0.668 \\
New CEO & 0.016 & 0.016 & 0.000 & 0.000 & 0.760 & 1.000 \\
\% independent board & 2.237 & 2.222 & 2.303 & 2.284 & 0.395 & 0.419 \\
Log (Board size) & 0.800 & 0.789 & 0.800 & 0.791 & 0.395 & 0.148 \\
CEO is Chairman & 0.661 & 0.710 & 1.000 & 1.000 & 0.858 & 0.981 \\
Dual class shares & 0.022 & 0.022 & 0.000 & 0.000 & 0.858 & 1.000 \\
Staggered board & 0.328 & 0.328 & 0.000 & 0.000 & 0.929 & 1.000 \\
\% board appointed by CEO & 0.470 & 0.451 & 0.500 & 0.414 & 1.000 & 0.834 \\
Institutional ownership & 0.781 & 0.769 & 0.865 & 0.854 & 0.929 & 0.668 \\
Block holders & 1.742 & 1.726 & 2.000 & 1.000 & 1.000 & 0.995 \\
Comp. committee - \% busy & 0.582 & 0.578 & 0.615 & 0.613 & 0.716 & 0.951 \\
Comp. committee - \% old & 0.260 & 0.247 & 0.250 & 0.242 & 0.716 & 0.286 \\
Log (Comp. committee size) & 1.287 & 1.292 & 1.309 & 1.309 & 0.501 & 0.995 \\
\hline
\end{tabular}




\section{Mean Median t- $\quad$ Signed \\ $\mathrm{N}$ difference difference statistic rank}

Compensation

Log (Total Compensation)

$\begin{array}{llllll}181 & 22.29 \% & 21.40 \% & 4.18 & * * * & 3,497\end{array} * * *$

\section{Components of compensation}

Log (Salary \& Benefits)

Log (Cash incentive pay)

Log (Equity pay)

$\begin{array}{cccccc}8.14 \% & 3.55 \% & 2.54 & * * & 1,923 & * * * \\ 7.13 \% & 6.01 \% & 1.21 & & 924 & \\ 22.20 \% & 15.49 \% & 3.54 & * * * & 2,463 & * * * \\ & & & & & \\ 7.1 \mathrm{pp} & 2.2 \mathrm{pp} & 4.06 & * * * & 2,797 & * * * \\ 4.3 \mathrm{pp} & 2.4 \mathrm{pp} & 1.55 & & 1,030 & \\ -1 \mathrm{pp} & 0 \mathrm{pp} & -0.24 & & -93 & \end{array}$

CEO Deferred Comp (\% of Total Comp)

$\begin{array}{llll}0.3 \mathrm{pp} & 0 \mathrm{pp} & -0.76 & -391\end{array}$

CEO Options (\% of Firm's Total Option Exp.)

Top 5 Exec Options (\% of Firm's Total Option Exp.)

Log (CEO's Options Avg. Remaining Vesting Period)

$\begin{array}{llll}0.2 \mathrm{pp} & -0.8 \mathrm{pp} & -0.11 & 284\end{array}$

$\begin{array}{llll}-2.8 \mathrm{pp} & -1.2 \mathrm{pp} & 0.82 & 251\end{array}$

$\begin{array}{llll}-0.02 & 0.00 & 0.61 & 74\end{array}$

\section{Firm performance}

$\triangle \mathrm{ROA}(\mathrm{t})$

$\begin{array}{llll}-0.1 \mathrm{pp} & 0.3 \mathrm{pp} & -0.26 & 248\end{array}$

Stock return $(\mathrm{t})$

$32.9 \mathrm{pp} \quad-0.2 \mathrm{pp} \quad 1.44 \quad 914$

Employee growth (t)

$-1.3 \mathrm{pp} \quad-1.9 \mathrm{pp} \quad-0.75$

$-961$

Asset growth (t)

$-0.3 \mathrm{pp}$

$-1.7 \mathrm{pp}$

$-0.16$

$-763$


Table 8. The effect of consultant turnover on pay around the additional disclosure requirement of 2009

\section{Panel A. Remain with multiservice consultant vs. switching to related spin-off specialist consultants}

This table reports a matched-pairs analysis of firms that remain with multiservice consultants instead of switching to related spin-off specialist consultants after the 2009 disclosure change. Matching is based on the propensity to switch to a related specialist from a multiservice consultant from firm, CEO, and governance characteristics (explanatory variables shown in Table 6). Panel A1 shows pre-2009 differences in pay comparing firms that switch to a related spin-off specialist firms to those that stay with the same multiservice consultant after the disclosure change. Panel A2 shows post-2009 differences in pay comparing firms that switch to a related spin-off specialist firms to those that stay with the same multiservice consultant. Variables are as defined in Appendix II.

Panel A1: Matched Pairs, pre-2009

\begin{tabular}{|c|c|c|c|}
\hline $\mathrm{N}$ & $\begin{array}{c}\text { Mean } \\
\text { difference }\end{array}$ & $\begin{array}{c}\text { Median } \\
\text { difference }\end{array}$ & $\begin{array}{c}\mathrm{t}- \\
\text { statistic }\end{array}$ \\
\hline
\end{tabular}

\section{Compensation}

Log (Total Compensation)

\begin{tabular}{cccccc}
$236-13.91 \%$ & $-13.68 \%$ & -3.73 & $* * *$ & $-3,419$ & $* * *$ \\
& & & & & \\
$-8.06 \%$ & $-6.61 \%$ & -3.39 & $* * *$ & $-3,913$ & $* * *$ \\
$-14.98 \%$ & $-10.12 \%$ & -4.06 & $* * *$ & $-3,513$ & $* * *$ \\
$-10.01 \%$ & $-6.06 \%$ & -2.01 & $* *$ & $-1,689$ & $*$ \\
& & & & & \\
$-2.3 \mathrm{pp}$ & $-1.3 \mathrm{pp}$ & -2.15 & $* *$ & $-1,734$ & $*$ \\
$-0.3 \mathrm{pp}$ & $0.5 \mathrm{pp}$ & -0.18 & & 193 & \\
$8.3 \mathrm{pp}$ & $10.6 \mathrm{pp}$ & 2.53 & $* *$ & 2,439 & $* * *$ \\
& & & & & \\
$-0.3 \mathrm{pp}$ & $0 \mathrm{pp}$ & -1.16 & & -653 & \\
$0.4 \mathrm{pp}$ & $-0.3 \mathrm{pp}$ & 0.32 & & 32 & \\
$3.3 \mathrm{pp}$ & $-0.2 \mathrm{pp}$ & 1.25 & & 226 & \\
-0.01 & 0.00 & -0.22 & & -20 & \\
& & & & & \\
$0.2 \mathrm{pp}$ & $-0.1 \mathrm{pp}$ & 0.65 & & 326 & \\
$0.5 \mathrm{pp}$ & $-5.1 \mathrm{pp}$ & 0.08 & & -180 & \\
$2.3 \mathrm{pp}$ & $2.4 \mathrm{pp}$ & 1.98 & $* *$ & 2,091 & $* *$ \\
$0.1 \mathrm{pp}$ & $0.5 \mathrm{pp}$ & 0.09 & & 100 & \\
\hline
\end{tabular}

\section{Components of compensation}

Log (Salary \& Benefits)

$\log$ (Cash incentive pay)

Log (Equity pay)

Proportion incentive pay $(\mathrm{t})$

Equity incentive pay $\%(\mathrm{t})$

Options as a \% of Equity Pay $(t)$

CEO Deferred Comp (\% of Total Comp)

CEO Options (\% of Firm's Total Option Exp.)

Top 5 Exec Options (\% of Firm's Total Option Exp.)

Log (CEO's Options Avg. Remaining Vesting Period)

\section{Firm performance}

$\triangle \mathrm{ROA}(\mathrm{t})$

Stock return $(\mathrm{t})$

Employee growth $(\mathrm{t})$

Asset growth (t) test 


\section{Mean Median t- Signed \\ $\mathrm{N}$ difference difference statistic rank}

\section{Compensation}

Log (Total Compensation)

$\begin{array}{lllllll}236 & -13.48 \% & -18.32 \% & -3.29 & * * * & -3,483 & * * *\end{array}$

\section{Components of compensation}

Log (Salary \& Benefits)

Log (Cash incentive pay)

Log (Equity pay)

$\begin{array}{llllll}-9.62 \% & -6.66 \% & -3.89 & * * * & -4,559 & * * * \\ -11.42 \% & -9.50 \% & -2.54 & * * & -2,157 & * *\end{array}$

Proportion incentive pay $(\mathrm{t})$

Equity incentive pay $\%(\mathrm{t})$

Options as a \% of Equity Pay $(\mathrm{t})$

$-9.52 \%$

$-10.95 \%$

$-1.82$

$-2,198 * * *$

CEO Deferred Comp (\% of Total Comp)

$\begin{array}{llll}-1.6 \mathrm{pp} & -1 \mathrm{pp} & -1.35 & -1,236\end{array}$

$\begin{array}{llll}1.3 \mathrm{pp} & -0.6 \mathrm{pp} & 0.64 & 322\end{array}$

$\begin{array}{llll}2.4 \mathrm{pp} & 0 \mathrm{pp} & 0.83 & 739\end{array}$

CEO Options (\% of Firm's Total Option Exp.)

$\begin{array}{llll}-0.2 \mathrm{pp} & 0 \mathrm{pp} & -0.73 & -143\end{array}$

$\begin{array}{llll}0.1 \mathrm{pp} & 0.8 \mathrm{pp} & 0.06 & 155\end{array}$

Top 5 Exec Options (\% of Firm's Total Option Exp.)

Log (CEO's Options Avg. Remaining Vesting Period)

$2.2 \mathrm{pp} \quad 0.87$

243

$\begin{array}{llll}-0.02 & 0.00 & -0.77 & -196\end{array}$

Firm performance

$\triangle \mathrm{ROA}(\mathrm{t})$

Stock return $(\mathrm{t})$

$\begin{array}{lllll}-0.5 \mathrm{pp} & -0.5 \mathrm{pp} & -1.46 & -2,203 & * *\end{array}$

Employee growth $(\mathrm{t})$

$\begin{array}{lllll}-4.5 \mathrm{pp} & -1.7 \mathrm{pp} & -1.71 & * & -343\end{array}$

Asset growth (t)

$\begin{array}{lllll}3.7 \mathrm{pp} & 1.2 \mathrm{pp} & 2.37 & * * & 1,589\end{array}$

$\begin{array}{llll}2.1 \mathrm{pp} & 0.7 \mathrm{pp} & 1.61 & 284\end{array}$ 


\section{Panel B. Remain with multiservice consultant vs. switching to unrelated specialist}

This table reports a matched-pairs analysis of firms that remain with multiservice consultants instead of switching to unrelated specialist consultants after the 2009 disclosure change. Matching is based on the propensity to switch to an unrelated specialist from a multiservice consultant from firm, CEO, and governance characteristics (explanatory variables shown in Table 6). Panel B1 shows pre-2009 differences in pay comparing firms that switch to an unrelated specialist firms to those that stay with the same multiservice consultant after the disclosure change. Panel B2 shows post-2009 differences in pay comparing firms that switch to an unrelated specialist firms to those that stay with the same multiservice consultant. Variables are as defined in Appendix II.

Panel B1: Matched Pairs, pre-2009

\begin{tabular}{|c|c|c|}
\hline $\begin{array}{c}\text { Mean } \\
\text { difference }\end{array}$ & $\begin{array}{l}\text { Median } \\
\text { difference }\end{array}$ & $\begin{array}{c}\mathrm{t}- \\
\text { statistic }\end{array}$ \\
\hline
\end{tabular}

\section{Compensation}

Log (Total Compensation)

$\begin{array}{lllll}187 & -4.00 \% & -2.21 \% & -0.86 & -751\end{array}$

\section{Components of compensation}

Log (Salary \& Benefits)

Log (Cash incentive pay)

Log (Equity pay)

$\begin{array}{cccccc}-0.62 \% & -1.83 \% & -0.31 & & -368 & \\ -10.74 \% & -9.72 \% & -2.37 & * * & -1,693 & * * \\ -1.74 \% & 3.28 \% & -0.31 & & -282 & \end{array}$

Proportion incentive pay $(\mathrm{t})$

Equity incentive pay $\%(\mathrm{t})$

Options as a \% of Equity Pay ( $t$ )

$\begin{array}{cccccc}0.2 \mathrm{pp} & 0.1 \mathrm{pp} & 0.10 & & 83 & \\ 3.9 \mathrm{pp} & 4.4 \mathrm{pp} & 1.82 & * & 1,379 & * \\ 6.7 \mathrm{pp} & 4.9 \mathrm{pp} & 2.03 & * * & 1,374 & * * \\ & & & & & \\ 0.4 \mathrm{pp} & 0 \mathrm{pp} & 2.43 & * * & 853 & * \\ -1.2 \mathrm{pp} & 0.3 \mathrm{pp} & -0.55 & & 90 & \\ -0.7 \mathrm{pp} & 0.4 \mathrm{pp} & -0.23 & & 88 & \\ 0.02 & 0.02 & 0.49 & & 140 & \end{array}$

Firm performance

$\triangle \mathrm{ROA}(\mathrm{t})$

Stock return $(\mathrm{t})$

Employee growth (t)

$0.3 \mathrm{pp} \quad 0.2 \mathrm{pp} \quad 1.2$

$1.24 \quad 1,194 * *$

$2.7 \mathrm{pp} \quad 7.9 \mathrm{pp}$

0.30

$3.1 \mathrm{pp} \quad 2 \mathrm{pp}$

2.13

$1.1 \mathrm{pp}$

$1.8 \mathrm{pp}$

0.55

406

** $\quad 1,488$

945 


\begin{tabular}{|c|c|c|c|c|}
\hline $\mathrm{N}$ & $\begin{array}{c}\text { Mean } \\
\text { difference }\end{array}$ & $\begin{array}{l}\text { Median } \\
\text { difference }\end{array}$ & $\begin{array}{c}\mathrm{t}- \\
\text { statistic }\end{array}$ & $\begin{array}{c}\text { Signed } \\
\text { rank } \\
\text { test }\end{array}$ \\
\hline
\end{tabular}

\section{Compensation}

Log (Total Compensation)

\section{Components of compensation}

Log (Salary \& Benefits)

Log (Cash incentive pay)

Log (Equity pay)

Proportion incentive pay $(\mathrm{t})$

Equity incentive pay $\%(\mathrm{t})$

Options as a \% of Equity Pay ( $\mathrm{t}$ )

CEO Deferred Comp (\% of Total Comp)

CEO Options (\% of Firm's Total Option Exp.)

Top 5 Exec Options (\% of Firm's Total Option Exp.)

Log (CEO's Options Avg. Remaining Vesting Period)
187

$-7.70 \%$

$-4.53 \%$

$-1.60$

$-963$

$\begin{array}{cccccc}0.40 \% & 0.54 \% & 0.17 & & 13 & \\ -5.55 \% & -5.81 \% & -1.18 & & -721 & \\ -11.08 \% & -4.05 \% & -1.89 & * & -1,331 & *\end{array}$

$-1.7 \mathrm{pp}$

$0.3 \mathrm{pp}$

$-1.10$

$-522$

$-1 \mathrm{pp}$

$-0.5 \mathrm{pp}$

$-0.47$

$-570$

$5 \mathrm{pp}$

$0 \mathrm{pp}$

1.32

723

$0.5 \mathrm{pp} \quad 0 \mathrm{pp}$

2.22

$1.9 \mathrm{pp}$

$1.4 \mathrm{pp}$

0.90

**

1,227

131

$1.4 \mathrm{pp}$

$2.7 \mathrm{pp}$

0.36

0.02

0.04

0.49

104

98

$\begin{array}{ccccc}0 \mathrm{pp} & -0.1 \mathrm{pp} & 0.00 & & -40 \\ -27 \mathrm{pp} & -14.4 \mathrm{pp} & -1.28 & & -1,026 \\ -2 \mathrm{pp} & -0.4 \mathrm{pp} & -1.71 & * & -916 \\ -2 \mathrm{pp} & 0.3 \mathrm{pp} & -1.62 & & -489\end{array}$

Firm performance

$\triangle$ ROA (t)

Stock return $(\mathrm{t})$

Employee growth (t)

Asset growth ( $\mathrm{t}$ ) 


\section{Table 9. Matched pairs analysis using changes on initial consultant adoption}

This table reports the difference in changes in compensation for a matched sample of firms that start using a compensation consultant. Client firms that enter the compensation consultant market are matched to firms that do not use a compensation consultant. Matching is based on propensity scores to start hiring a compensation consultant (using firm, CEO, and governance characteristics in Table 6) using 1:1 caliper matching. The mean and median differences report both the change in compensation for a client firm that decides to start using a compensation consultant market, compared to the change for a matched firm that does not use a consultant, and the pre-adoption difference in pay levels. Firmyears with CEO turnover are excluded. Variables are as defined in Appendix II.

\begin{tabular}{|c|c|c|c|c|}
\hline $\mathrm{V}$ & $\begin{array}{c}\text { Mean } \\
\text { difference }\end{array}$ & $\begin{array}{c}\text { Median } \\
\text { difference }\end{array}$ & $\begin{array}{c}\mathrm{t}- \\
\text { statistic }\end{array}$ & $\begin{array}{c}\text { Signed } \\
\text { rank } \\
\text { test }\end{array}$ \\
\hline
\end{tabular}

\section{Changes in compensation}

$\Delta \log$ (Total compensation)

113

$\begin{array}{ccccc}15.98 \% & -6.44 \% & 2.20 & * * & 554 \\ 0.88 \% & 0.21 \% & 0.39 & & 89 \\ 2.72 \% & 1.75 \% & 0.34 & & 43 \\ 19.93 \% & 2.14 \% & 2.48 & * * & 568 \\ 1.6 \mathrm{pp} & -0.2 \mathrm{pp} & 0.56 & & 48 \\ 6.9 \mathrm{pp} & 0.3 \mathrm{pp} & 1.72 & * & 564 \\ 2 \mathrm{pp} & 0 \mathrm{pp} & 0.52 & & 19 \\ & & & & \\ -0.7 \mathrm{pp} & 0 \mathrm{pp} & -1.75 & * & -91 \\ -1.2 \mathrm{pp} & 0.3 \mathrm{pp} & -0.40 & & -11 \\ -0.9 \mathrm{pp} & -1.9 \mathrm{pp} & -0.20 & & -41 \\ -2.8 \mathrm{pp} & -1.6 \mathrm{pp} & -1.14 & & -11\end{array}$

$\Delta \log$ (Non-incentive pay)

$\Delta \log$ (Cash incent. pay)

$\Delta \log$ (Equity pay)

$\Delta$ Proportion incentive pay

$\Delta$ Equity incentive pay $\%(\mathrm{t})$

$\Delta$ Options as a $\%$ of Equity Pay $(\mathrm{t})$

$\triangle$ CEO Deferred Comp ( $\%$ of Total Comp)

$\triangle$ CEO Options (\% of Firm's Total Option Exp.)

$\Delta$ Log (CEO's Options Avg. Remaining Vesting Period)

$\Delta$ Top 5 Exec Options (\% of Firm's Total Option Exp.)

$-2.8 \mathrm{pp}$

$-1.6 \mathrm{pp}$

$\begin{array}{lcccc}1.6 \mathrm{pp} & 0.2 \mathrm{pp} & 1.78 & * & 277 \\ 3.3 \mathrm{pp} & 12 \mathrm{pp} & 0.10 & & 118 \\ 4.1 \mathrm{pp} & 0.7 \mathrm{pp} & 2.03 & * * & 384 \\ 3.9 \mathrm{pp} & -0.3 \mathrm{pp} & 1.36 & & 256\end{array}$

\section{Firm performance}

$\triangle \mathrm{ROA}(\mathrm{t})$

Stock return $(\mathrm{t})$

Employee growth (t)

Asset growth (t)

\section{Pre-Adoption Levels}

Log (Total compensation)

Log (Salary \& Benefits)

Log (Cash incentive pay)

Log (Equity pay)

Proportion incentive pay $(\mathrm{t})$

Equity incentive pay \% (t)

Options as a $\%$ of Equity Pay (t)

CEO Deferred Comp (\% of Total Comp)

CEO Options (\% of Firm's Total Option Exp.)

Log (CEO's Options Avg. Remaining Vesting Period)

Top 5 Exec Options (\% of Firm's Total Option Exp.)

\section{3}

\begin{tabular}{cc}
$6.32 \%$ & $-2.55 \%$ \\
$-0.59 \%$ & $-4.59 \%$ \\
$-74.60 \%$ & $6.00 \%$ \\
$-22.56 \%$ & $0.00 \%$ \\
$4.3 \mathrm{pp}$ & $0.7 \mathrm{pp}$ \\
$4.5 \mathrm{pp}$ & $0 \mathrm{pp}$ \\
$-4.3 \mathrm{pp}$ & $0 \mathrm{pp}$ \\
& \\
$0.4 \mathrm{pp}$ & $0 \mathrm{pp}$ \\
$-0.6 \mathrm{pp}$ & $3.3 \mathrm{pp}$ \\
$3.5 \mathrm{pp}$ & $8.9 \mathrm{pp}$ \\
$-10.8 \mathrm{pp}$ & $-10.5 \mathrm{pp}$ \\
\hline
\end{tabular}

0.63

$-0.93$

370

$-0.32$

173

263

1.16

285

$-71$

$-0.55$

$\begin{array}{ll}1.16 & 10\end{array}$

$-0.16$

89

109

$-166$ 